UNIVERSIDADE DE SÃO PAULO

FACULDADE DE ZOOTECNIA E ENGENHARIA DE ALIMENTOS

ANNA LUIZA FARIAS ALENCAR

Isolamento e caracterização de estirpe de Frog Virus 3-símile detectada em rãs-touro gigante (Lithobates catesbeianus) no Estado de São Paulo 
Isolamento e caracterização de estirpe de Frog Virus 3-símile detectada em rãs-touro gigante (Lithobates catesbeianus) no Estado de São Paulo

Versão corrigida

Dissertação apresentada à Faculdade de Zootecnia e Engenharia de Alimentos da Universidade de São Paulo, como parte dos requisitos para a obtenção do título de Mestre em Ciências.

Área de Concentração: Biociência Animal

Orientador: Prof. Dr. Ricardo Luiz Moro de Sousa 
Ficha catalográfica elaborada pelo Serviço de Biblioteca e Informação, FZEA/USP, com os dados fornecidos pelo(a) autor(a)

Alencar, Anna Luiza Farias

Isolamento e caracterização de estirpe de Frog

Virus 3-símile detectada em rãs-touro gigante

(Lithobates catesbeianus) no Estado de São Paulo /

Anna Luiza Farias Alencar ; orientador Ricardo Luiz

Moro Sousa. -- Pirassununga, 2016.

$60 \mathrm{f}$.

Dissertação (Mestrado - Programa de Pós-Graduação em Biociência Animal) - Faculdade de Zootecnia e Engenharia de Alimentos, Universidade de São Paulo.

1. isolamento viral. 2. cultivo celular. 3. anfíbios. 4. Ranavirus. I. Sousa, Ricardo Luiz Moro, orient. II. Título. 


\section{Isolamento e caracterização de estirpe de Frog Virus 3-símile detectada em rãs-touro gigante (Lithobates catesbeianus) no Estado de São Paulo}

Dissertação apresentada à Faculdade de Zootecnia e Engenharia de Alimentos da Universidade de São Paulo, como parte dos requisitos para a obtenção do título de Mestre em Ciências.

Área de Concentração: Biociência Animal

Data de aprovação:

Banca examinadora:

Prof (a). Dr (a). Instituição:

Julgamento: Assinatura:

Prof (a). Dr (a). Instituição:

Julgamento: Assinatura:

Prof (a). Dr (a). Instituição:

Julgamento: Assinatura: 


\section{AGRADECIMENTOS}

Aos meus pais, por terem me ofertado tudo o que era essencial, me guiado e por continuarem cuidando e olhando por mim, onde quer que eles estejam.

Ao Prof. Dr. Ricardo Luiz Moro de Sousa por ter me apresentado ao mundo dos vírus e da biologia molecular e mais recentemente do cultivo celular (!), pelas oportunidades, orientação (muitas vezes não só acadêmica!), paciência, confiança e exemplo.

A Profa. Dra. Andrezza Fernandes pelos conselhos, piadas, caronas, dicas e orientação.

A FAPESP por todo o apoio financeiro neste projeto (2014/03463-4) assim como na BEPE (2015/04027-6), a qual me proporcionou uma oportunidade única de trabalhar com pesquisadores-referência na área e me abriu muitas portas.

A Ana Paula Araujo, Santiago de Pádua e Roney Nogueira pela concessão de amostras, informações e ajuda com a microscopia eletrônica.

A minha irmã Anna Emília, por aguentar os trancos da vida junto comigo.

Ao Troels Rundqvist, pelo amor, carinho, paciência, por tentar manter minha fé na humanidade e me familiarizar ao mundo dinamarquês.

Ao Arthur Mendes, pela paciência, amor e carinho.

A técnica Silvia Godoy por toda a ajuda, amizade, carinho, caronas e lanchinhos.

Aos colegas e amigos que fiz nestes anos de mestrado: Loiane Sampaio, Marisa França (bora tomar uma coca?), Marina Massoco, Carolina Maria, Marcela Jimenez, Thais Correa, Samara Maganha, Sabrina Almeida-Queiroz e aos antigos e de sempre: Erika Peluque (cabeçona), Euder Joseph, Juliana Baldin, Eurico Arruda (cabeção), Juliana Navarro, Marina Rosa, Andrea Vasquez, Bruna Heloise, Raul Fregonesi, Tiago Lucera, Patricia Jojima, Barbara Ferro, Ana Carolina Campos, Edilson Guerra, Lu Machado e Maria Fernanda Burbarelli..

Aos meus inesquecíveis colegas de turma e professores da VETPIRA 01 e principalmente às girls: Cryskely Batinga, Anna Carolina Ercolin, Jaqueline Diniz, Lillian Gonzalez, Daniella Freitas e Vivian Ríspoli.

Ao pessoal do DTU Veterinærinstituttet, que me ensinou muito mais do que somente doenças de peixes: Professor Niels Jørgen Olesen, Niccolò Vendramin, Didde Hedegaard Sørensen, Susie Sommer Mikkelsen, Betina Lynnerup, Christina Flink Desler, Teena Vendel Klinge, Tine Moesgaard Iburg, Lone Madsen e também a todas as pessoas fantásticas que conheci na escandinávia: Lubomir, Linus, Demian, Åsa, Åsa, Tom, Anders \& Elin, Anna \& Per, Emma, Leise, Manuela.

Aos meus familiares em João Pessoa e Campina Grande, especialmente as tias Maria, Verlandia e Valnice por todo o apoio e oração.

A todos os meus amigos dentro e fora da universidade. Especialmente: Vanessa Figueredo, Guilherme Scagion, Renata Salles, Rodrigo Barreto, Juliana Casals, Mateus Oliveira, Raphael Campos, Ana Carolina Negreiros, Luciano Geronimo, Aline Dibbern, Gueivson Anjos, Felipe Perissato, Arthur Gabriel de Santana, Laila Gallo e Antoine Peronnet. 
"Here is your shield against violence, here is your sword: faith in our lives and human dignity. For all our children's sake, search for, and plant it. Die if you must, but increase it and strengthen it."

Nordahl Grieg 


\section{RESUMO}

ALENCAR, A. L. F. Isolamento e caracterização de estirpe de Frog Virus 3-símile detectada em rãs-touro gigante (Lithobates catesbeianus) no Estado de São Paulo. 2016. 61 f. Dissertação (Mestrado) - Faculdade de Zootecnia e Engenharia de Alimentos, Universidade de São Paulo, Pirassununga, 2016.

A aquicultura é apontada como um mercado estratégico para o desenvolvimento sustentável, produção de alimentos e ampliação de fronteiras inexploradas no Brasil. No entanto, como outros sistemas de produção animal, este setor enfrenta problemas com doenças resultantes de sua intensificação, como os aspectos sanitários da produção e a falta de estrutura para o diagnóstico das principais enfermidades infecciosas. Durante os últimos 20 anos, os vírus da família Iridoviridae, em especial membros do gênero Ranavirus, têm sido responsáveis por epizootias de grande impacto ecológico e econômico, envolvendo um grande número de espécies de peixes, anfíbios e répteis de importância na aquicultura de várias partes do mundo. No entanto, as informações sobre a ocorrência de infecções de peixes e anfíbios causadas por ranavírus no Brasil são limitadas. O presente projeto compreendeu o isolamento em cultivo celular de estirpe de Frog Virus 3-símile, no Estado de São Paulo, confirmada por sequenciamento nucleotídico do gene MCP e subsequente RFLP, assim como caracterização fenotípica e de cinética de replicação do isolado. Amostras de fígado, baço e rins de rãs-touro gigante provenientes de ranário comercial, positivas ao diagnóstico molecular para Ranavirus, foram utilizadas para isolamento viral em cultivo celular. Efeito citopático foi detectado na segunda passagem em células BF-2 e posterior confirmação do isolamento foi feita por PCR e RFLP. A caracterização fenotípica viral foi feita com microscopia eletrônica de transmissão, a qual permitiu a confirmação de morfologia semelhante às partículas de Ranavirus, além da realização de curva de replicação, indicando maiores títulos virais no quarto dia após inoculação. Também foi feito teste de susceptibilidade a solventes, que confirmou a presença de partículas envelopadas. Os resultados obtidos nesse estudo poderão contribuir para a futura compreensão da biologia dos iridovírus circulantes como agentes etiológicos de ranaviroses em anfíbios no Estado de São Paulo.

Palavras-chave: Isolamento. Cultivo celular. Anfíbios. Ranavirus. 


\begin{abstract}
Alencar, A. L. F. Isolation and characterization of Frog Virus 3-like strain detected in american bull frogs (Lithobates catesbeianus) in São Paulo State. 2016. 61 f. M.Sc. Dissertation - Faculdade de Zootecnia e Engenharia de Alimentos, Universidade de São Paulo, Pirassununga, 2016.

Aquaculture is appointed as a strategic market for sustainable development, food production and expansion of unexplored frontiers in Brazil. However, just like other animal production systems, this area faces problems due its intensification, like the production sanitation aspects and the lack of structure for the diagnosis of major infectious diseases. During the last 20 years, viruses from Iridoviridae family, especially Ranavirus genera, have been responsible for major economic and ecological impactant epizootic diseases in a great number of fish, amphibian and reptile species in many parts of the world. However, information on the occurrence of infections in fishes and amphibians caused by ranavirus in Brazil are limited. In this context, this project aimed to isolate a Frog Virus 3-like strain detected in São Paulo state in cell culture, which was later confirmed by nucleotide sequencing of MCP gene and further RLFP technique and also phenotipical characterization and replication kinetics of the obtained strain. Liver, spleen and kidney samples from american bullfrogs from commercial frog ponds, positive by molecular diagnostic for Ranavirus, were used for viral isolation in cell culture. Citopathic effect was detected during the second passage in cells and later confirmed by PCR and RFLP. The viral characterization was carried out with transmission electronic microscopy, which confirmed similar morphology of viral particles to those of Ranavirus, besides the construction of a growth curve which indicated larger titres on the fourth day post inoculation. A test for solvent sensitivity was also performed and confirmed the presence of enveloped particles. The results obtained in this study will contribute to the understanding of the biology of the circulating iridovirus in São Paulo state as an etiological agent of ranavirus infection in amphibians.
\end{abstract}

Keywords: Isolation. Cell culture. Amphibians. Ranavirus. 


\section{LISTA DE FIGURAS}

Figura 1 - Produção aquícola brasileira entre 1980 e 2011 ..............................................17

Figura 2 - Rã-touro americana (Lithobates catesbeianus)...............................................18

Figura 3 - Produção da ranicultura mundial (em toneladas)............................................19

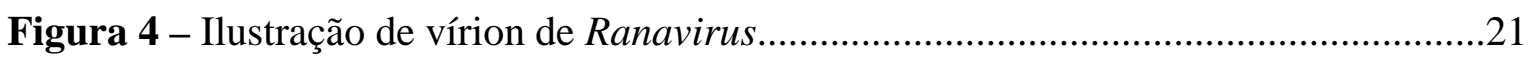

Figura 5 - Distribuição de casos de ranaviroses no mundo..............................................22

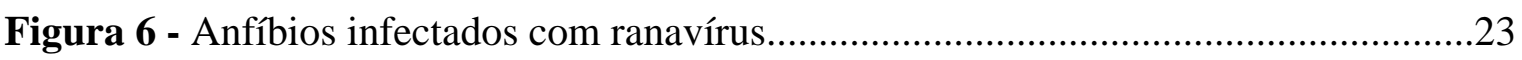

Figura 7 - Fotografia de microscopia eletrônica de transmissão de cultivo de iridovírus obtido do fígado de uma rã naturalmente infectada (Rana temporaria) em células epiteliais

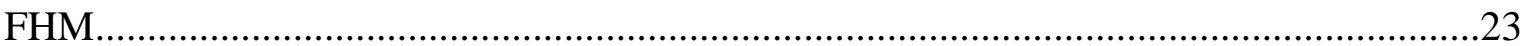

Figura 8 - Monocamada de células BF-2 em adaptação gradual a concentrações de Fungizone $^{\circledR}$.

Figura 9 - Células inoculadas com a segunda passagem (P2) da amostra 154 utilizadas na extração de DNA 36

Figura 10 - Efeito citopático de ranavírus em monocamada de BF-2 inoculada com a amostra 154 na passagem 1 (P1). .36

Figura 11 - Efeito citopático de ranavírus em monocamada de BF-2 inoculada com a amostra 154 na segunda passagem (P2).

Figura 12 - Efeito citopático de ranavírus em monocamada de BF-2 inoculada com a amostra 151 na segunda passagem (P2), no sexto dia após inoculação.

Figura 13 - Fotografia de gel de agarose a 1,5\% corado com SYBR ${ }^{\circledR}$ Gold, sob luz UV, ilustrando resultados de amplificação por PCR dos fragmentos MCP1 (321pb) e MCP2 (625pb) da proteína principal do capsídeo de ranavírus (MCP), a partir de DNA extraído da $2^{\mathrm{a}}$ passagem da amostra 154 em células BF-2.

Figura 14 - Fotografia de gel de agarose a 1,5\% corado com SYBR ${ }^{\circledR}$ Gold, sob luz UV, ilustrando resultados de amplificação completa por PCR do gene MCP (1483pb) de ranavírus, a partir de DNA extraído da $2^{\mathrm{a}}$ passagem da amostra 154 em células BF2.

Figura 15 - Fotografia de gel de agarose a 3,0\% corado com SYBR ${ }^{\circledR}$ Gold, sob luz UV, ilustrando resultados de digestão por enzimas de restrição dos fragmentos MCP1 e MCP2 obtidos para a amostra 154 
Figura 16 - Alinhamento entre as sequências deduzidas de aminoácidos do gene MCP de ranavírus para as amostras 154 e Frog Virus 3 (número de acesso GenBank: KJ175144)

Figura 17 - Micrografia eletrônica de transmissão de cultivo de BF-2 infectado com a amostra 154 . .43

Figura 18 - Micrografia eletrônica de transmissão de cultivo de BF-2 infectado com a amostra 154 .44

Figura 19 - Curva de replicação: TCID $_{50} / \mathrm{mL}$ de acordo com o tempo de infecção do ranavírus isolado.

Figura 20 - Cultivo celular infectado com a 5a passagem da amostra 154RV em cultura de BF-2 durante os três primeiros dias pós-inoculação para a realização da curva de replicação.

Figura 21 - Cultivo celular infectado com a $5^{\text {a }}$ passagem da amostra 154RV durante os três últimos dias pós-inoculação para a realização da curva de replicação

Figura 22 - Contraste negativo de microscopia eletrônica de transmissão destacando partícula viral envelopada .50

Figura 23 - Títulos (TCID ${ }_{50} / \mathrm{mL}$ ) de dez isolados virais nos dias 6, 8 e 14 após inoculação em células EPC a $24^{\circ} \mathrm{C}$ 


\section{LISTA DE TABELAS}

Tabela 1 - Primers a serem utilizados nas reações de PCR para confirmação do isolamento de ranavírus.

Tabela 2 - Análise de polimorfismo no comprimento de fragmentos obtidos por digestão enzimática dos amplicons do gene MCP obtidos por PCR

Tabela 3 - Valores de TCID $_{50} / \mathrm{mL}$ obtidos a partir da curva de replicação viral em cada tempo de coleta..... .46 


\section{LISTA DE ABREVIATURAS E SIGLAS}

ATCC: American Type Culture Collection

ATV: Ambystoma tigrinum vírus

BF-2: Bluegill fry - linhagem celular

BIV: Bohle iridovirus

$\mathbf{C O}_{2}$ : Dióxido de carbono

DNA: ácido desoxirribonucleico

ECV: Vírus do bagre europeu

EDTA: ácido etilenodiamino tetra-acético

EHNV: Vírus da necrose hematopoiética epizoótica

EPC: Epithelioma Papulosum Cyprini - linhagem celular

FV3: Frog virus 3

MEM: Minimum Essential Medium

MCP: Proteína principal do capsídeo

OIE: Organização Internacional das Epizootias

PCR: Reação em cadeia da polimerase

RFLP: Análise de polimorfismo no comprimento de fragmentos por digestão enzimática SCRV: Santee-Cooper ranavirus

TAE: tampão Tris-Acetato-EDTA

TCID $_{50}:$ 50\% Tissue Culture Infective Dose 


\section{SUMÁRIO}

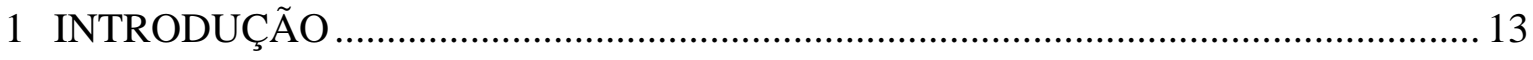

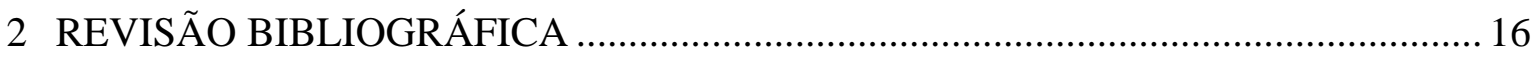

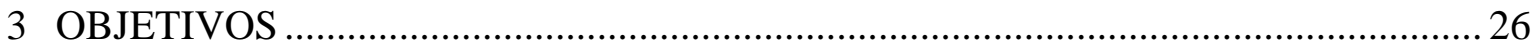

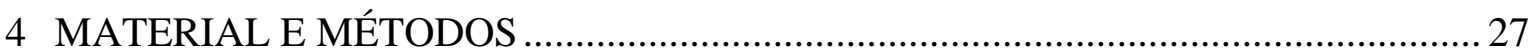

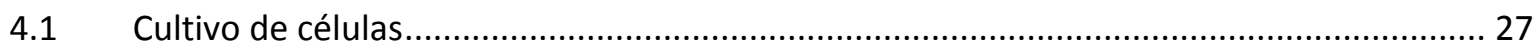

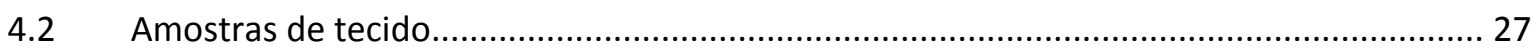

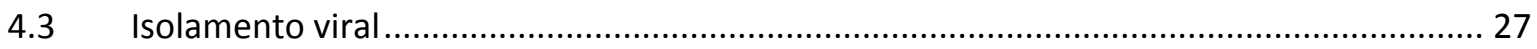

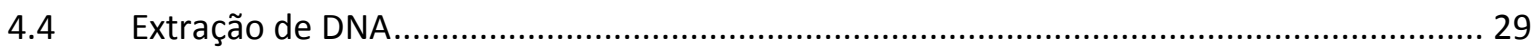

4.5 PCR e análise de polimorfismo no comprimento de fragmentos obtidos por digestão enzimática (RFLP) para confirmação do isolamento e identificação da estirpe viral. ....................... 29

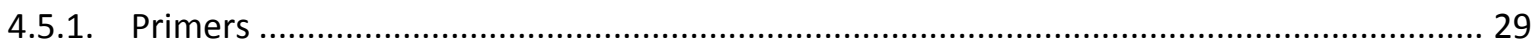

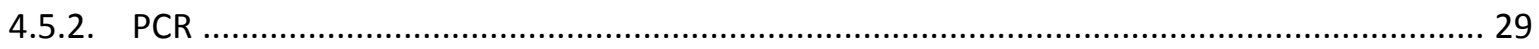

4.5.3. Análise de polimorfismo no comprimento de fragmentos obtidos por digestão enzimática (RFLP) 30

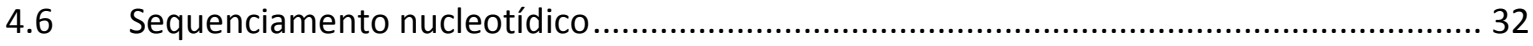

4.7 Microscopia Eletrônica de Transmissão ........................................................................ 32

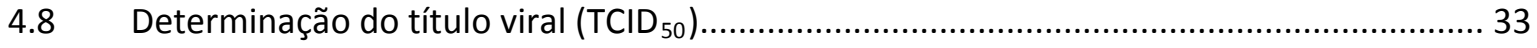

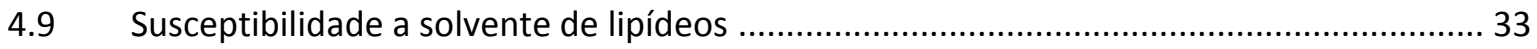

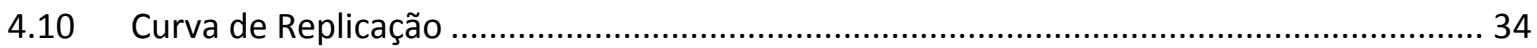

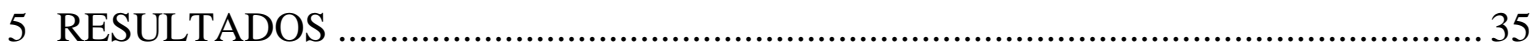

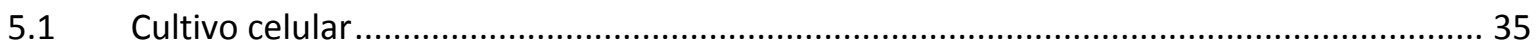

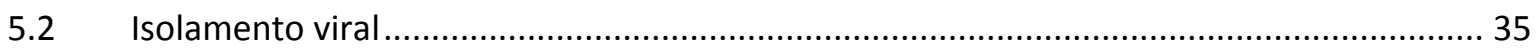

5.3 PCR e análise de polimorfismo no comprimento de fragmentos obtidos por digestão enzimática (RFLP) para confirmação do isolamento e identificação da estirpe viral ...................... 38

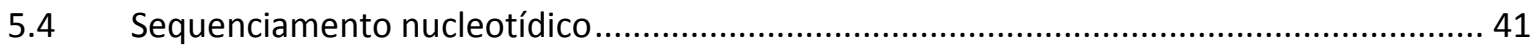

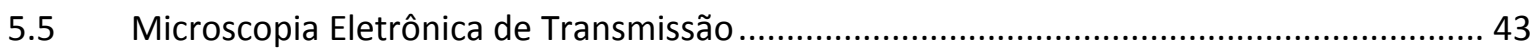

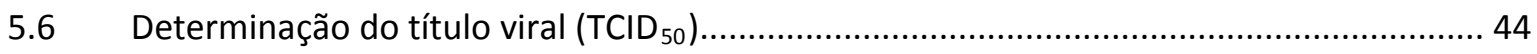

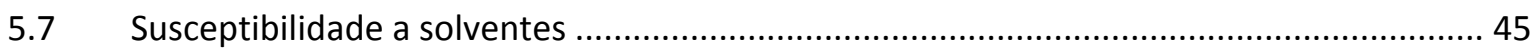

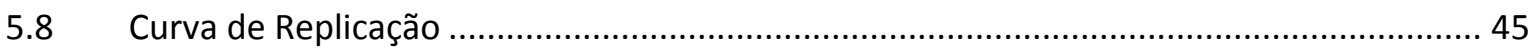

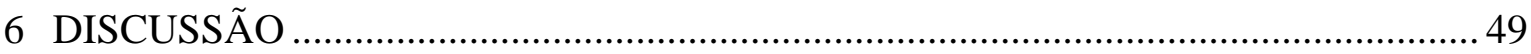

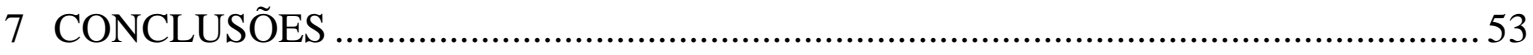




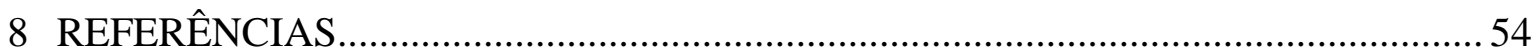

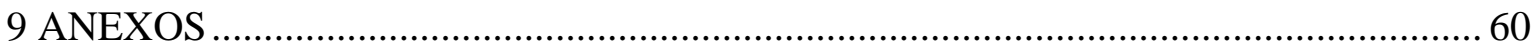




\section{INTRODUÇÃO}

A ranicultura brasileira desperta grande interesse junto a investidores e empresas devido ao elevado potencial produtivo, eficiência de conversão alimentar das espécies de interesse zootécnico e bom retorno financeiro com o comércio de carne e subprodutos (LIMA; AGOSTINHO, 1989).

A carne de rã é considerada mais saudável quando comparada à carne de outros animais devido ao menor teor de gordura (3\%), menor porcentagem de calorias, por ser a única carne produzida em cativeiro que contém os 10 aminoácidos básicos para os seres humanos e por ter alta digestibilidade, podendo inclusive ser indicada para crianças com sensibilidade digestiva a outras proteínas de origem animal (LIMA; AGOSTINHO, 1995).

A espécie mais utilizada nos ranários comerciais brasileiros é a Rana catesbeiana (rã-touro gigante), reclassificada como Lithobates catesbeianus, a qual tem sua origem nos Estados Unidos e que se adaptou perfeitamente às condições climáticas, bem como à criação intensiva no Brasil (FERREIRA, 2004; FROST et al., 2006). Além disso, sua precocidade, a alta taxa de reprodução e seu tamanho foram características determinantes para a substituição das rãs nativas pelas rãs-touro na criação intensiva.

O Brasil é hoje um país produtor de carne de rã, com os Estados de São Paulo, Goiás, Minas Gerais, Rio de Janeiro e Distrito Federal sendo responsáveis por 97\% de toda a produção (cerca de 400 toneladas/ano) (LIMA; CRUZ; MOURA, 1999; CARRARO, 2008).

A intensificação das criações permitiu o aumento da densidade populacional e, consequentemente, maior exposição a eventuais patógenos. No entanto, a identificação dos agentes etiológicos e a escolha de tratamento adequado não são facilmente realizadas devido ao aparecimento de sintomas inespecíficos e à falta de informações referentes à sanidade destes animais (GALLI et al., 2006). O declínio da população de anfíbios no meio ambiente é um assunto bastante atual e um dos problemas ambientais mais enigmáticos e preocupantes do final do século 20. Assim como no meio ambiente, nas criações comerciais existe uma alta ocorrência de casos de mortalidade de animais sem causa definida. O manejo incorreto, a destruição do habitat, a introdução de predadores ou competidores, o aumento de radiação ultravioleta, a chuva ácida, as alterações climáticas, a poluição ambiental e as doenças infecciosas emergentes são as hipóteses mais discutidas (DASZAK et al., 1999; HIPOLITO et al., 2003). Dadas as ameaças atuais aos anfíbios, o 
desenvolvimento de planos para a proteção da sua diversidade é crucial, requerendo-se um profundo conhecimento das ameaças atuais e futuras (ALFORD, 2011).

Neste contexto, dentre as doenças reconhecidas como mais importantes causas do declínio das populações de anfíbios destacam-se as ranaviroses, causadas pelos iridovírus do gênero Ranavirus (FOX et al., 2006; GALLI et al., 2006; MAZZONI, 2006).

As ranaviroses são reconhecidas como importantes doenças emergentes em animais de sangue frio, com rápida propagação e alta letalidade, inclusive, de notificação obrigatória à Organização Mundial de Saúde Animal (OIE, 2016; ANTONUCCI, 2009). As ranaviroses possuem ampla especificidade de hospedeiros, sugerindo um grande potencial para transmissão interespécies e interclasses, ambos já demonstrados em experimentos e podem infectar anfíbios répteis e peixes (CUNNINGHAM et al., 2007). Contudo, a compreensão sobre as variações de hospedeiro e da geografia dos ranavírus são dificultadas pela falta de caracterização do vírus, visto que a designação de espécies ou genotipos, como o FV3, é baseada quase que exclusivamente no gene codificante da proteína principal do capsídeo (Major Capsid Protein - MCP) (LESBARRERES et al., 2012; BANDIN; DOPAZO, 2011).

A mortalidade e morbidade variam conforme a espécie. No Brasil, a circulação de ranavírus, com forte suspeita da presença de FV3, já foi sugerida por Galli et al. (2006) em evento de mortalidade em massa em girinos da espécie Rana catesbeiana. O primeiro relato de mortalidade de girinos doentes por ranavirose no país foi descrito em Goiás por Mazzoni et al. (2009) que detectaram e caracterizaram a infecção por técnicas moleculares, histopatológicas e microscopia eletrônica.

Investigações sobre o controle e prevenção das ranaviroses ainda permanecem limitadas, adotando-se basicamente a melhoria das condições de manejo higiênico, como quarentena, desinfecção de tanques e sacrifício de animais infectados, uma vez que não há vacinas comerciais disponíveis (WHITTINGTON; BECKER; DENNIS, 2010). Os vírus da família Iridoviridae representam ameaça à aquicultura comercial, à biodiversidade e à conservação de espécies de peixes e anfíbios de vida livre; contudo, dados epidemiológicos disponíveis para uma grande variedade de vírus são mínimos (WHITTINGTON; BECKER; DENNIS, 2010).

Diante do impacto econômico provocado por doenças causadas por membros da família Iridoviridae, sobretudo em peixes, aliado à escassez de informações sobre a sua ocorrência no Brasil, seja como agentes primários de quadros clínicos ou ainda subclínicos, potencializando a susceptibilidade a outros agentes infecciosos, e da importância da 
aquicultura para a produção zootécnica brasileira, torna-se premente a realização de investigações visando à detecção e caracterizção de iridovírus em espécimes brasileiros, bem como das doenças associadas a esses agentes. 


\section{REVISÃO BIBLIOGRÁFICA}

\subsection{Aquicultura no mundo e no Brasil}

A aquicultura é o setor de produção de alimentos de origem animal que cresce mais rápido no mundo e, de acordo com a Organização das Nações Unidas para Alimentação e Agricultura (FAO), atualmente ultrapassa o crescimento populacional (FOOD AND AGRICULTURE ORGANIZATION OF THE UNITED NATIONS - FAO, 2014). Ela se baseia na produção de peixes (piscicultura), moluscos (malacocultura), camarões (carcinicultura), algas (algicultura), rãs (ranicultura) e jacarés, estando a de peixes à frente com um montante anual de 44,1 milhões de toneladas, seguida pelos moluscos (15,2 milhões de toneladas) e crustáceos (6,4 milhões de toneladas) (FAO, 2013). A produção de pesca de captura está estabilizada mundialmente e a maior parte das áreas de pesca já alcançou seu potencial máximo. Para atender a demanda crescente de alimentos de origem aquática, a aquicultura está se desenvolvendo, expandindo e se intensificando em grande parte das regiões do mundo (FAO, 2014). Estimativas para 2030 predizem que a aquicultura será responsável por mais de $60 \%$ da produção mundial de pescados no mundo, assim dominando o fornecimento destes alimentos (FAO, 2013).

O Brasil se posiciona como um país promissor para o desenvolvimento da aquicultura devido à extensão de seus cursos d'agua, longa linha costeira, clima adequado e grande diversidade de espécies nativas com apelo comercial (SCORVO, 2004; MARTINS; HIPOLITO; CATROXO, 2011; CAMARGO; POUEY, 2005). A taxa de crescimento da aquicultura no Brasil já alcançou a taxa global, com um crescimento de 22\% ao ano, durante o período de 1997 a 2006, e o país aparece como $12^{\circ}$ maior produtor mundial (FAO, 2014; (BRASIL, 2015). No entanto, assim como qualquer outra produção animal, a aquicultura no Brasil também enfrenta problemas de intensificação. Aspectos relacionados à sanidade e a falta de infraestrutura para o diagnóstico das doenças infecciosas mais frequentes são considerados os maiores problemas que afetam o crescimento e produtividade das criações brasileiras (FIGUEIREDO; LEAL, 2008).

No Brasil, o Ministério da Pesca e Aquicultura, agora absorvido pelo Ministério da Agricultura, Pecuária e Abastecimento, recentemente estabeleceu um novo programa de legislação para assegurar a prevenção, controle e erradicação de doenças e contribuir para o aumento da produtividade, assim como também apresentou o Plano de Desenvolvimento Aquícola, para garantir o crescimento da produção de peixes no país para os próximos cinco anos (BRASIL, 2015). 
Figura 1 - Produção aquícola brasileira entre 1980 e 2011.

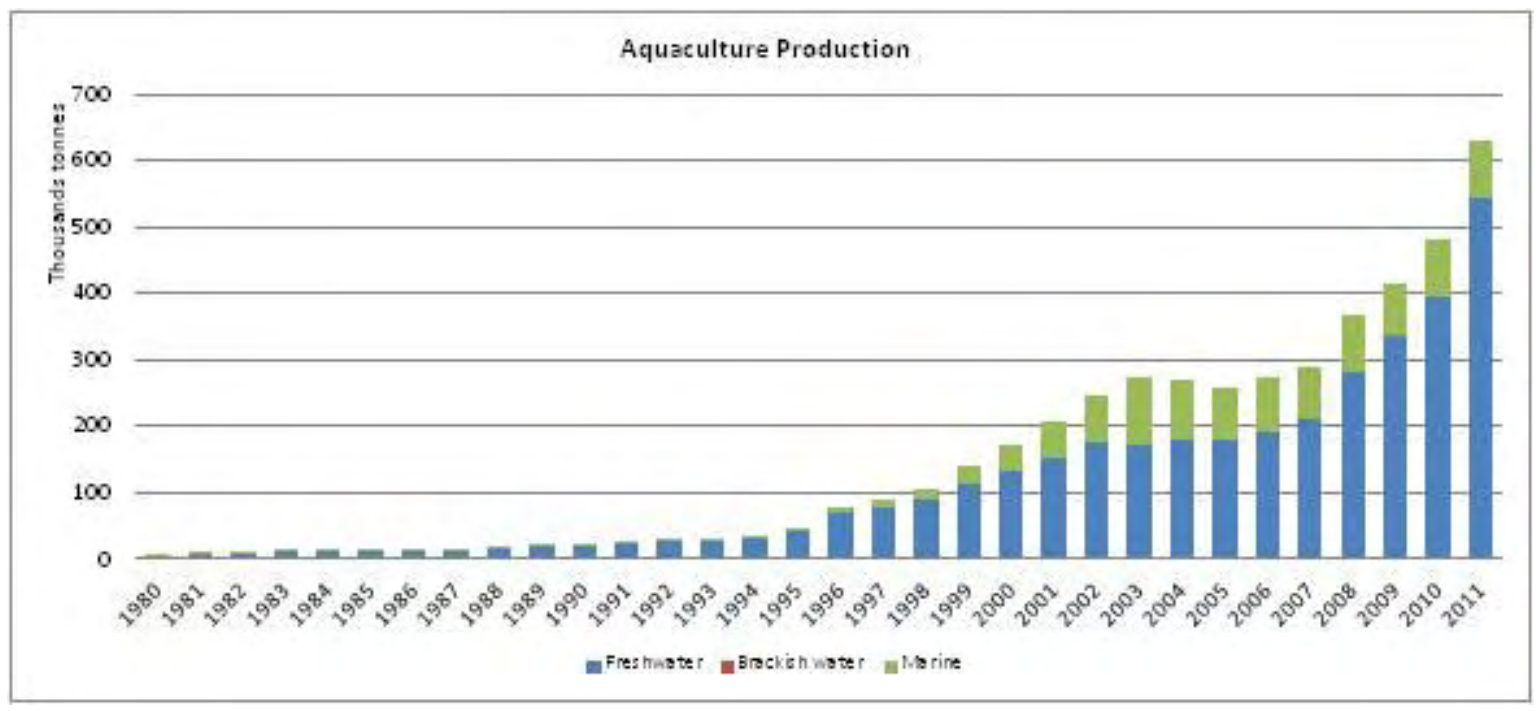

Fonte: FAO, 2013 (http://www.fao.org/fishery/facp/BRA/en).

O plano prevê o objetivo de se ampliar em 2 milhões de toneladas de pescado até o ano de 2020 com incentivos governamentais no sentido de facilitar o uso de águas e obtanção de licenciamentos ambientais com finalidade de produção aquícola, assim como apoio a assistência técnica, capacitação, extensão, gerenciamento das criações, pesquisa e desenvolvimento de tecnologias acessíveis aos produtores e outros benefícios. O plano também conta com o apoio da Agência Nacional de Águas (ANA) para garantir a sustentabilidade do projeto (BRASIL, 2015).

\subsection{Anfíbios e Ranicultura}

Atualmente, são reconhecidas 7530 espécies de anfíbios no mundo, os quais estão distribuídos em diversos tipos de habitats terrestres e aquáticos (AMPHIBIAWEB, 2016; FROST et al., 2006). Enquanto o número de espécies conhecidas aumenta, por conta do maior interesse e estudos recentes realizados, ocorre coincidentemente o declínio da população mundial de anfíbios, com estimativas de que um terço dessa população se encontra ameaçada ou já em extinção, sendo que no Brasil se encontra a maior diversidade de espécies de anfíbios no mundo (IUCN, 2008; AMPHIBIAWEB, 2016). O declínio da população de anfíbios no meio ambiente é um assunto bastante atual e um dos problemas ambientais mais enigmáticos e preocupantes do final do século 20. Assim como no meio ambiente, nas criações comerciais existe uma alta ocorrência de casos de mortalidade de 
animais sem causa definida. O manejo incorreto, a destruição do habitat, a introdução de predadores ou competidores, o aumento de radiação ultravioleta, a chuva ácida, as alterações climáticas, a poluição ambiental e as doenças infecciosas emergentes são as hipóteses mais discutidas (DASZAK et al., 1999; HIPOLITO et al., 2003). Dadas as ameaças atuais aos anfíbios, o desenvolvimento de planos para a proteção da sua diversidade é crucial, requerendo um profundo conhecimento das ameaças atuais e futuras (ALFORD, 2011).

Figura 2 - Rã-touro americana (Lithobates catesbeianus).

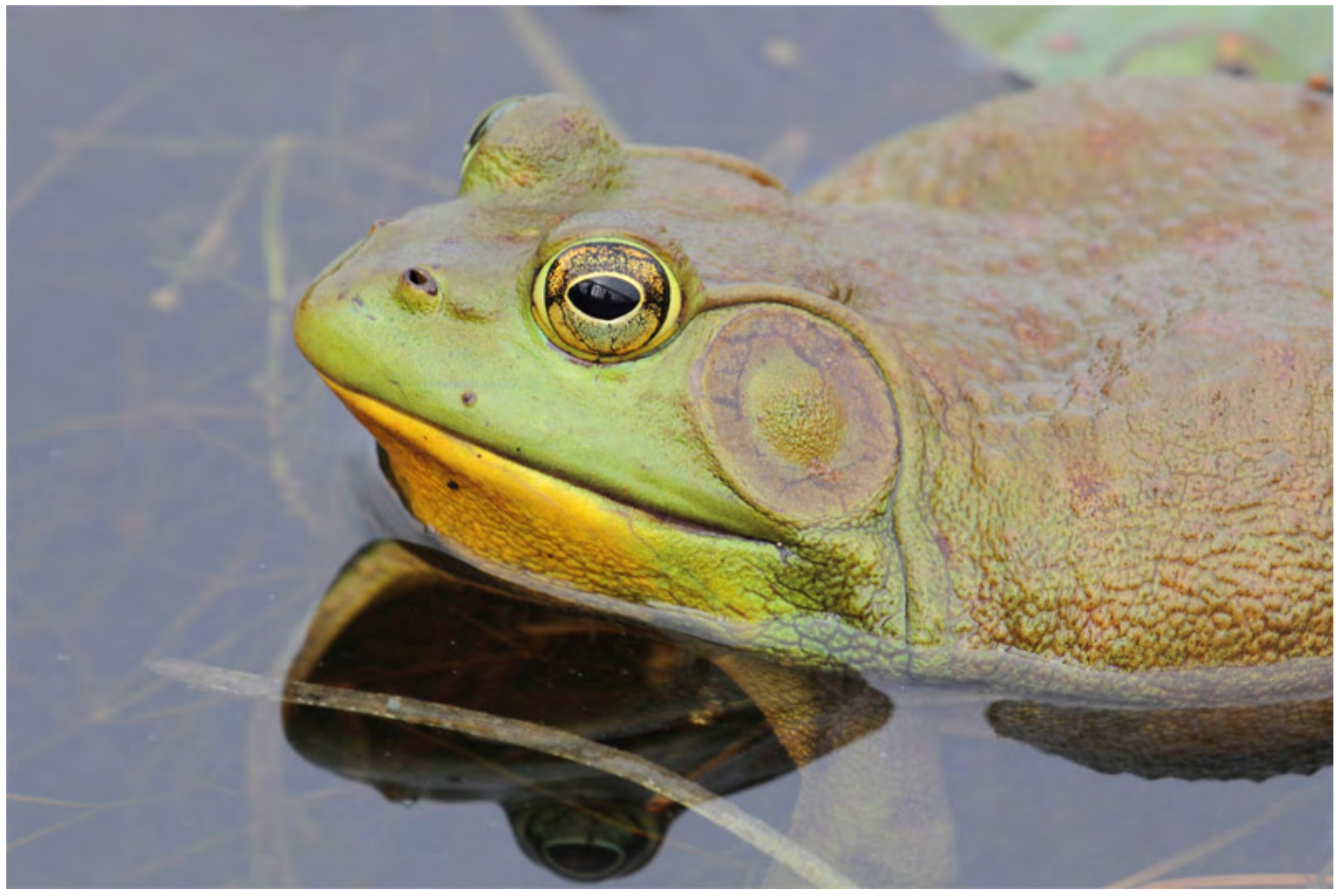

Fonte: Cephas (Autoria própria) [CC BY-SA 3.0 (http://creativecommons.org/licenses/by-sa/3.0)], via Wikimedia Commons.

Além da preocupação com as espécies silvestres, também existe a preocupação com as criações comerciais. A ranicultura compreende a produção de rãs em cativeiro com a finalidade comercial e tem como principal foco a criação de rãs-touro gigante (Lithobates catesbeianus). Esta espécie foi escolhida devido às suas características zootécnicas: precocidade, prolificidade e rusticidade além da perfeita adaptação às condições climáticas brasileiras, com desempenho produtivo superior quando comparado ao de espécies nativas (RODRIGUES et al., 2010; FERREIRA; PIMENTA; PAIVA NETO, 2002). O consumo da carne de rã é popular em alguns países, e esta é considerada saudável e recomendada 
por médicos e nutricionistas devido ao seu baixo teor de gordura, alta concentração de proteínas associada à alta digestibilidade e também pelo seu sabor semelhante ao da carne de frango (CARRARO, 2008). O Brasil se situa como o segundo maior produtor de rãs das Américas, com aproximadamente 400 toneladas por ano, direcionadas majoritariamente ao mercado externo, perdendo somente para a produção de Taiwan. No entanto, mesmo com uma alta produção, a demanda nacional não é atendida, fazendo com que a ranicultura se torne um negócio atrativo para novas empresas (SNA, 2013; CARRARO, 2008; FAO, 2016).

Figura 3 - Produção da ranicultura mundial (em toneladas)

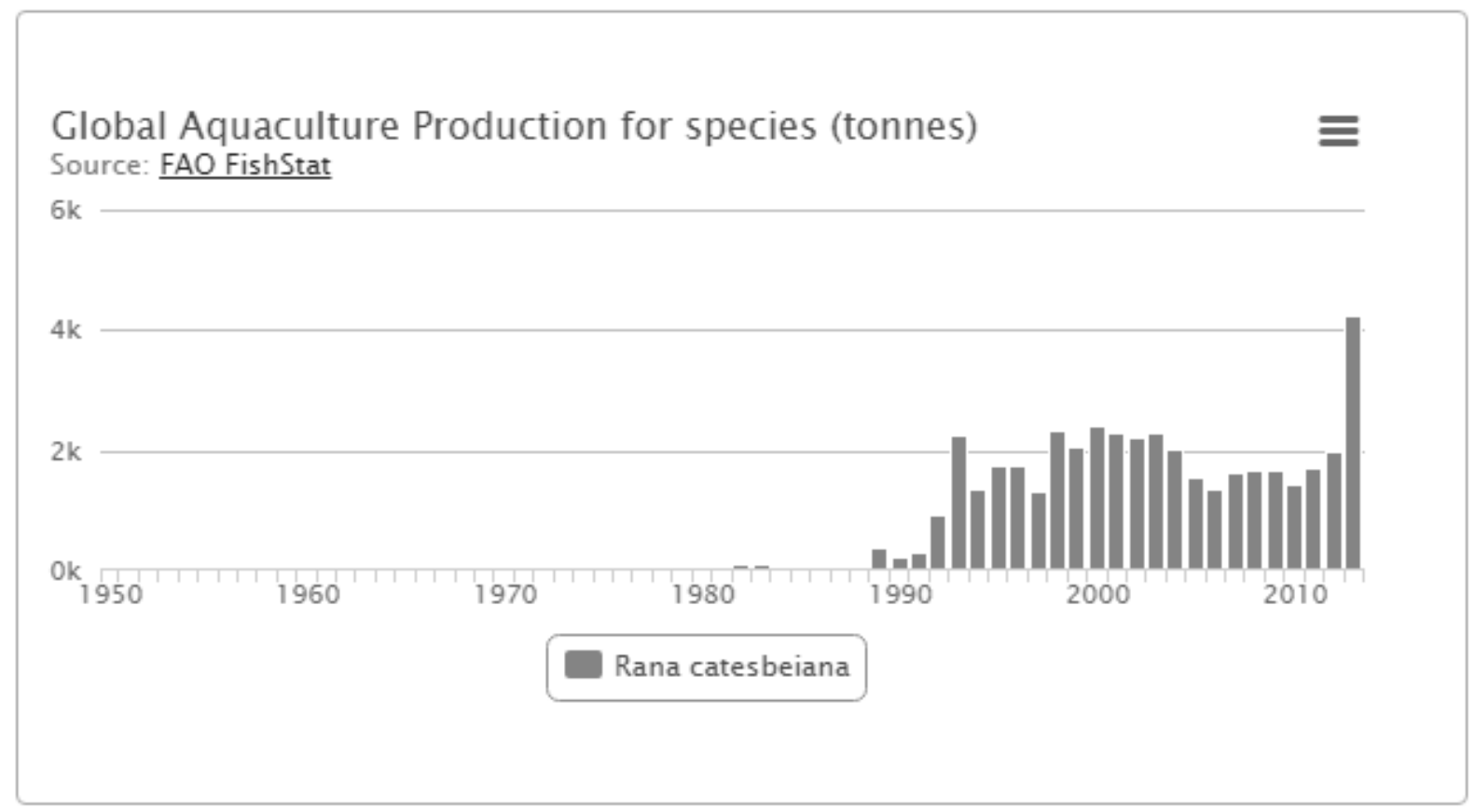

Legenda: Gráfico demonstrando a produção de rãs mundial nos últimos 30 anos. A maior parte da produção é proveniente de Taiwan seguido de criações com números significativos no Brasil, Equador e Guatemala.

Fonte: http://www.fao.org/fishery/culturedspecies/Rana_catesbeiana/en\#tcN800FE

O Brasil é apontado como o país que possui as melhores tecnologias para criação de rãs, uma vez que todo o processo é feito em condições controladas, evitando perdas por caça predatória, além das condições climáticas e ambientais favoráveis e também pela existência de instituições e recursos humanos competentes e voltados ao desenvolvimento da ranicultura (OLIVEIRA, 2015). A ranicultura brasileira teve seu início na década de 30, quando 300 animais foram trazidos do Canadá para o Brasil e logo após, nos anos 40, foram oferecidos incentivos e fomento para as criações pela Secretaria de Agricultura do Estado de São Paulo (MOREIRA, 2011). No entanto, a produção de rãs no 
país só teve maior valorização na década de 80 , com avanços em relação à produtividade relacionados com melhorias nas instalações, rações apropriadas, manutenção de temperatura, maior conhecimento dos animais e criação de índices zootécnicos (RODRIGUES et al., 2010).

Por outro lado, o aumento da tecnificação contribuiu para uma maior exposição dos animais, submetidos a regimes intensivos de produção, a potenciais agentes patogênicos, dado o maior adensamento populacional. Surtos com alta mortalidade em girinos e rãs são frequentes e acarretam grandes perdas econômicas. A identificação do agente etiológico causador geralmente é difícil, dada à sintomatologia inespecífica e à falta de informações disponíveis; contudo, causas nutricionais, tóxicas, relacionadas ao manejo e infecciosas são consideradas (GALLI et al., 2006; MAZZONI et al., 2009). As medidas mais eficazes para o controle de doenças em ranários são profiláticas e preventivas como o uso de pedilúvio e rodolúvio com desinfetantes na entrada da propriedade e instalações, a existência de instalações para desinfecção e higiene pessoal, a desinfecção e esterilização de utensílios, a remoção de cantos em pisos para se evitar lesões nos animais e acúmulo de resíduos, a redução da manipulação excessiva dos animais, a realização de quarentena em animais recém-chegados, o uso de ração de qualidade e em boas condições de estocagem, a realização de vazio sanitário, o monitoramento da qualidade da água, os programas de vacinação, embora ainda realizada de forma incipiente e o uso de aditivos alimentares (vitaminas, imunoestimulantes, probióticos e prebióticos) (PEREIRA et al., 2015).

Atualmente, a ranicultura passa por um momento favorável, com sua cadeia produtiva integrada, diversificação de produtos e grande abertura de mercado, tanto nacional quanto internacional. No entanto, a irregularidade da oferta dos produtos derivados de rãs, a desorganização do setor produtivo e o número baixo de abatedouros credenciados pelo setor de inspeção, aliados a baixos investimentos do setor público são desafios a serem superados (OLIVEIRA, 2015).

\subsection{Ranavirus}

O aumento do interesse e consequente aumento de informações sobre o declínio das espécies de anfíbios no mundo, alinhado a frequentes surtos com alta mortalidade em criações de rãs, concorreram para considerar os iridovírus como importantes agentes etiológicos em animais aquáticos silvestres e também de exploração zootécnica (MAZZONI et al., 2009; GALLI et al., 2006). 
Os iridovírus (família Iridoviridae) são vírus grandes (aproximadamente 120200nm de diâmetro), icosaédricos, possuem genoma linear de DNA de fita dupla (140 a 200Kb), podendo ser envelopados ou não como demonstrado na Figura 4 (CHINCHAR et al., 2009). A família Iridoviridae é composta por cinco gêneros: Iridovirus e Chloriridovirus (associados à insetos), Lymphocystivirus e Megalocytivirus (associados à algumas espécies de peixes) e o gênero Ranavirus. Este último é representado por seis espécies: Ambystoma tigrinum vírus (ATV), Bohle iridovirus (BIV), Epizootic haematopoietic necrosis virus (EHNV), European catfish virus (ECV), Frog virus 3 (FV3) e Santee-Cooper ranavirus (SCRV), sendo eles responsáveis por doenças sistêmicas em peixes, anfíbios e répteis (ICTVDS, 2006; WHITTINGTON; BECKER; DENNIS, 2010). O FV3 é o mais estudado e é amplamente usado como modelo para estudos envolvendo os iridovírus (CHINCHAR et al., 2009). As ranaviroses são reconhecidas como importantes doenças emergentes em animais de sangue frio, e são de notificação obrigatória à Organização Mundial de Saúde Animal (OIE, 2016; ANTONUCCI, 2009).

Figura 4 - Ilustração de vírion de Ranavirus

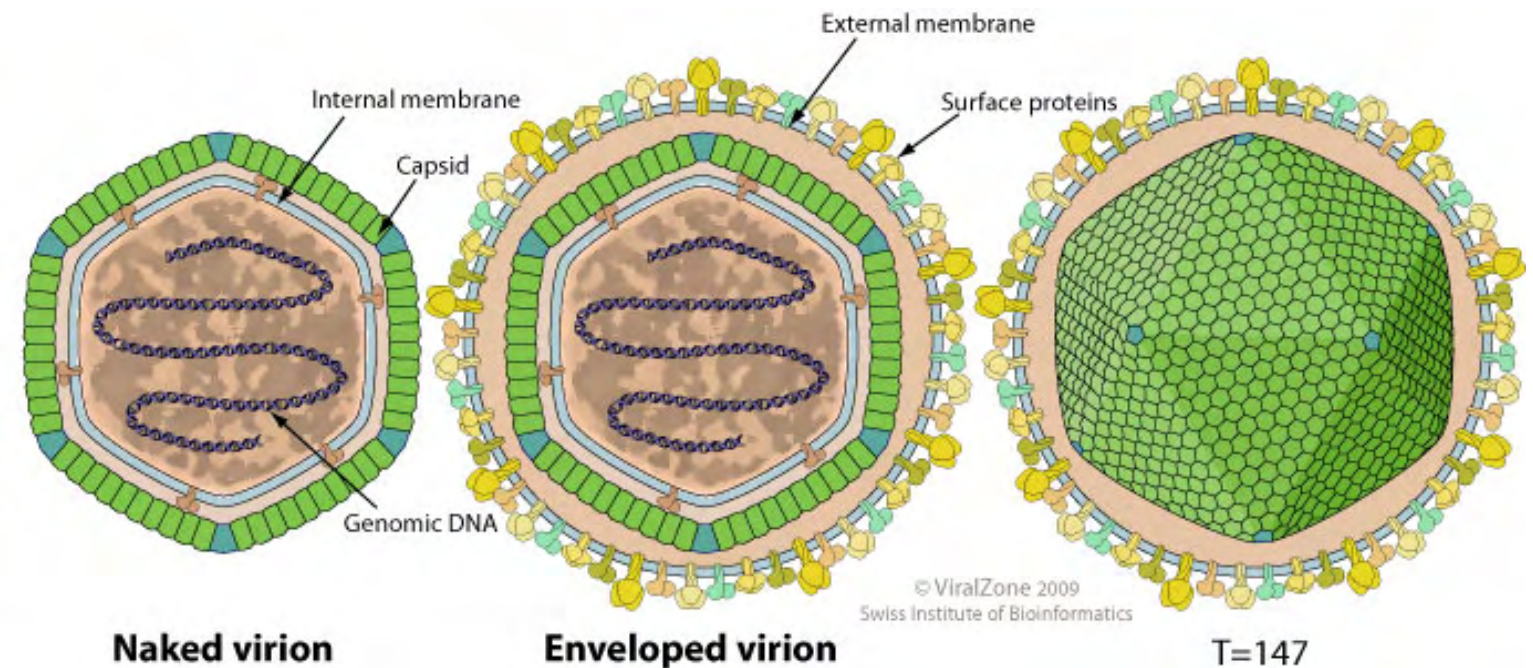

Legenda: Ilustração de ambos vírions não envelopados (naked virion) e envelopado (enveloped virion) mostrando as camadas internas e externas e proteínas de membrana.

Fonte: http://viralzone.expasy.org/all_by_species/585.html

Estudos relatam que os Ranavirus infectam ao menos 72 espécies de anfíbios em 14 famílias, sendo a maior parte dos casos na família Ranidae (MILLER et al., 2011). Diversas espécies de ranavírus já foram identificadas em infecções de rãs selvagens e cultivadas na Ásia, América do Norte, América do Sul, Austrália e Europa (CULLEN; OWENS, 2002; CUNNINGHAM et al., 1996; FOX et al., 2006; GALLI et al., 2006; MAZZONI et al., 2009; WOLF et al., 1968; ZHANG et al., 2001; ZUPANOVIC et al., 
1998), salamandras na América do Norte (BOLLINGER et al., 1999; DOCHERTY et al., 2003), peixes de espécies selvagens e cultivadas na Ásia, Austrália, Europa e América do Norte (AHNE et al., 1997; AHNE; SCHLOTFELDT; THOMSEN, 1989; LANGDON et al., 1986; NAKAJIMA; INOUYE; SORIMACHI, 1998; PLUMB et al., 1996), e em répteis na Europa, América do Norte, África e Ásia (CHEN; ZHENG; JIANG, 1999; DRURY; GOUGH; CALVERT, 2002; HYATT et al., 2002; MAO; HEDRICK; CHINCHAR, 1997; MARSCHANG et al., 1999; TELFORD; JACOBSON, 1993). Dada a distribuição global dos ranavírus e a sua capacidade de causar doenças em várias espécies, estes patógenos representam um risco às populações globais de anfíbios (MILLER et al., 2011).

Figura 5 - Distribuição dos casos de ranavirose no mundo.

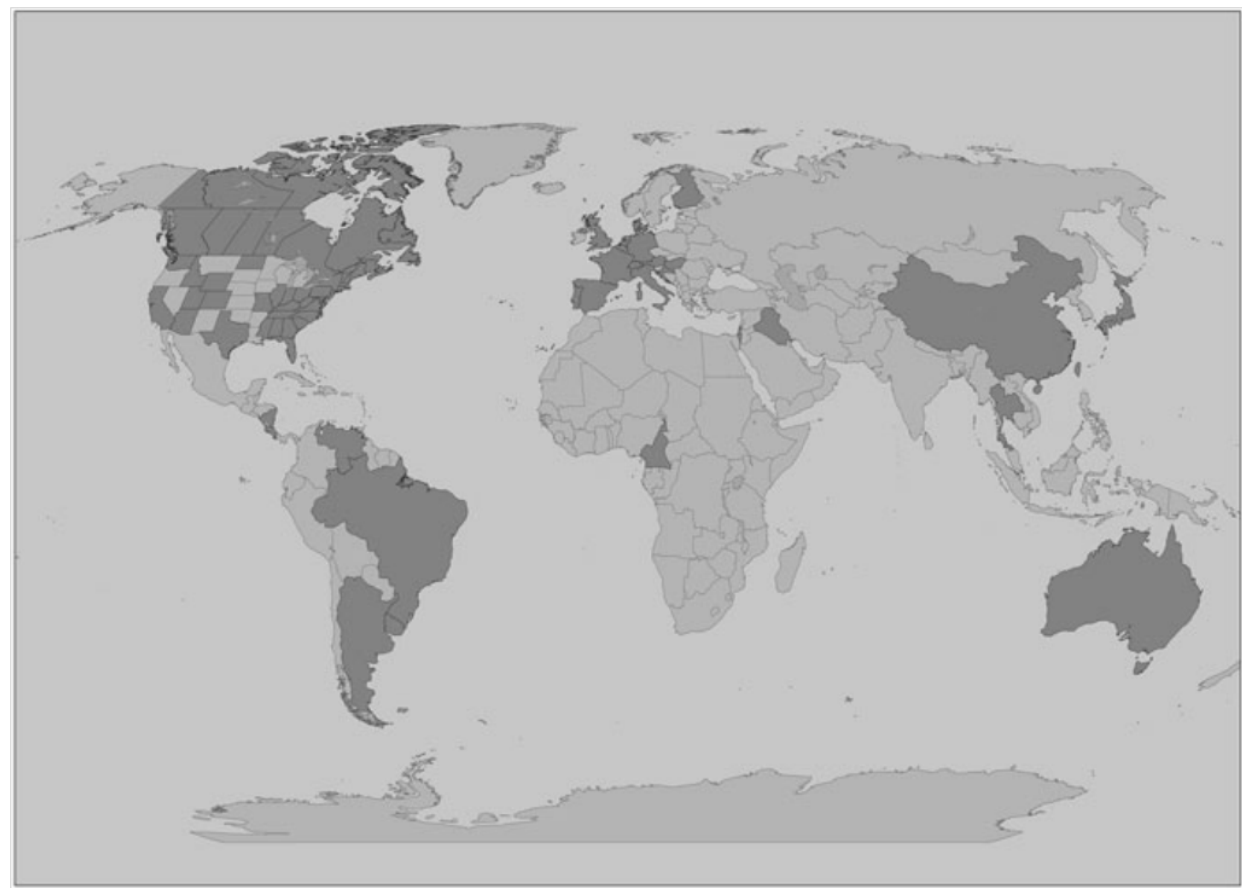

Fonte: DUFFUS, A. L. J. et al. Distribution and host range of ranaviruses. In: GRAY, M. J.; CHINCHAR, V. G. (Eds.). Ranaviruses: lethal pathogens of ectothermic vertebrates. New York: Springer International Publishing, 2015. p. 9-57.

A transmissão ocorre por contato direto com animais infectados, bem como por ingestão de indivíduos infectados, mortos ou moribundos. Partículas virais também podem ser encontradas na água dos rios e nos recintos aquáticos dos ranários (OIE, 2012). Os sinais clínicos em anfíbios doentes incluem uma síndrome ulcerativa crônica e uma síndrome hemorrágica aguda, enquanto que salamandras infectadas com Ambystoma tigrinum virus desenvolvem dermatite ulcerativa e enterite. Larvas afetadas apresentam diversos focos hemorrágicos afetando o tecido subcutâneo na região plantar das patas, na 
região inguinal e ventral, com edema. Ademais, BIV e FV3 causam hemorragia multifocal em diversos órgãos e necrose (OIE, 2012). A susceptibilidade dos hospedeiros aos ranavírus varia de acordo com o estágio de crescimento do animal, sendo os adultos menos susceptíveis provavelmente devido à imunocompetência adquirida. No entanto, a mortalidade de anfíbios adultos por ranavírus pode ser comum em criações em cativeiro por conta da alta densidade populacional, elevados títulos virais ou fatores ambientais estressantes (MILLER et al., 2011).

Figura 6 - Anfíbios infectados com ranavírus.
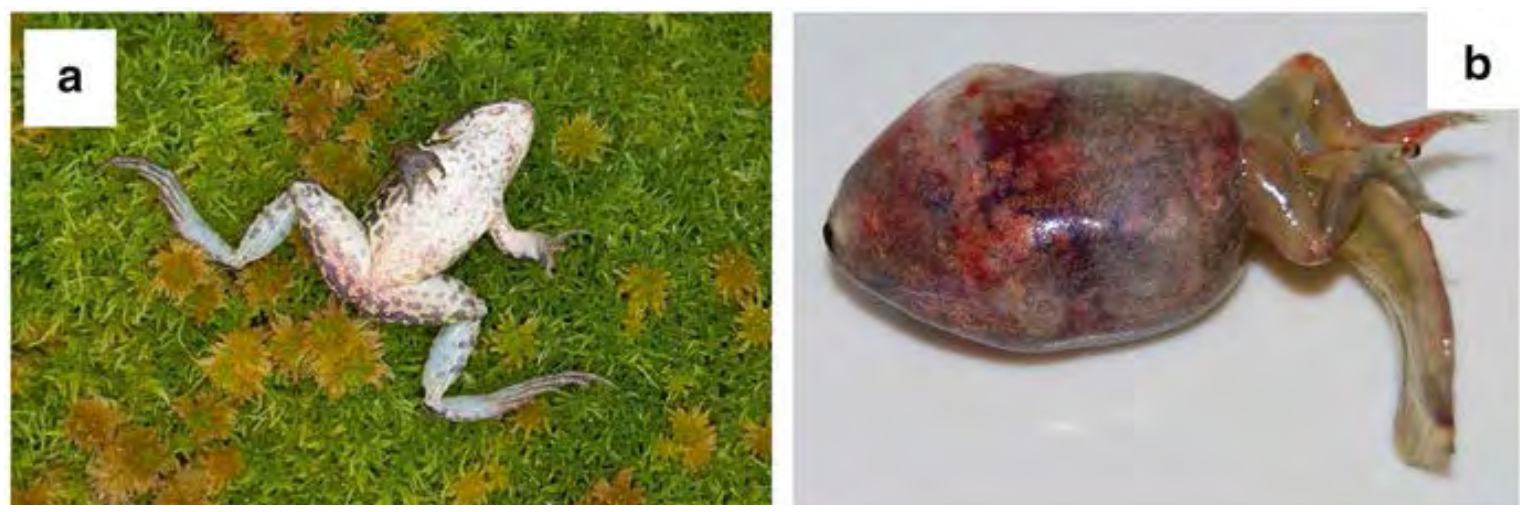

Legenda: a. Rã (Rana esculenta) comercial morta por infecção. b. Girino de Spea bombifrons afetado por infecção por Ranavirus.

Fonte: DUFFUS, A. L. J. et al. Distribution and host range of ranaviruses. In: GRAY, M. J.; CHINCHAR, V. G. (Eds.). Ranaviruses: lethal pathogens of ectothermic vertebrates. New York: Springer International Publishing, 2015. p. 9-57.

Figura 7 - Fotografia de microscopia eletrônica de transmissão de cultivo de iridovírus obtido do fígado de uma rã naturalmente infectada (Rana temporaria) em células epiteliais FHM.

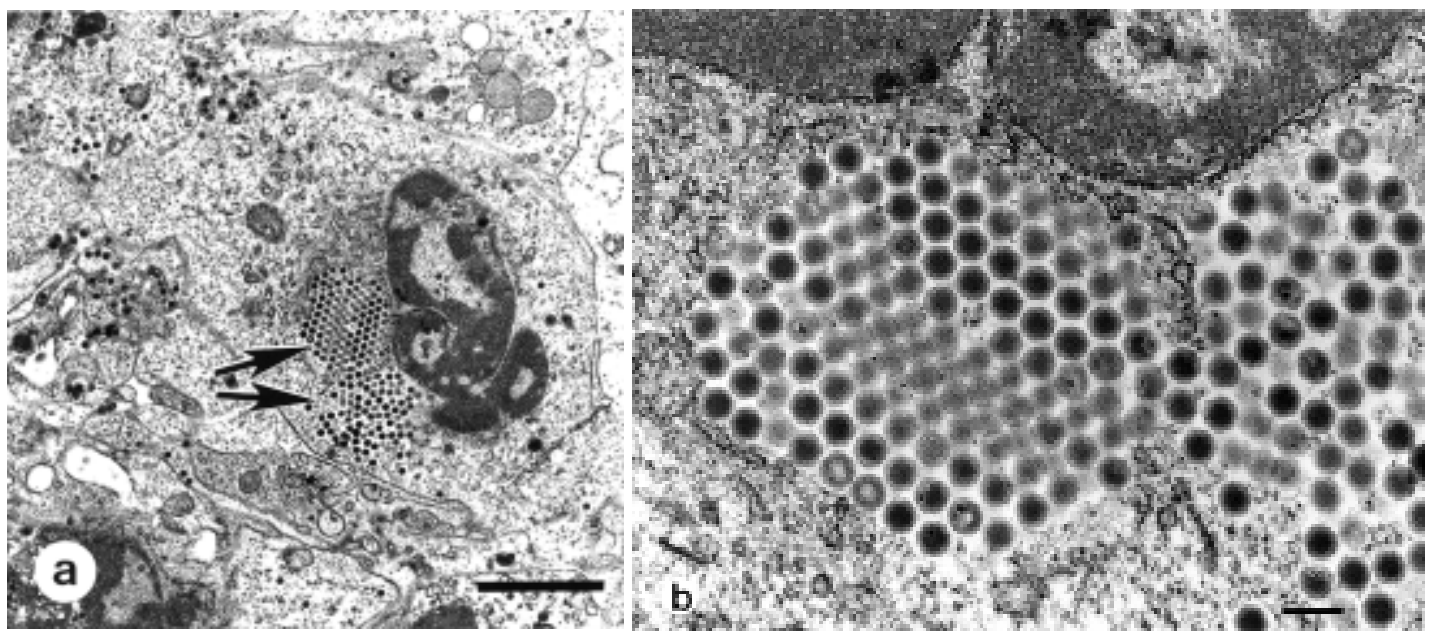

Legenda: a. Célula infectada por iridovírus. Partículas virais icosaédricas visíveis no citoplasma. Barra $=2 \mu \mathrm{m}$. b. Arranjo paracristalino típico dos iridovírus. Barra $=200 \mu \mathrm{m}$.

Fonte: DASZAK, P. et al. Emerging infectious diseases and amphibian population declines.

Emerging Infectious Diseases, Atlanta, v. 5, n. 6, p. 735-748, 1999. 
Os ranavírus são diferenciados dos outros gêneros da família Iridoviridae a partir do tamanho das partículas virais, quantidade de hospedeiros, presença da enzima DNA metiltransferase, conteúdo de GC e similaridade no gene MCP (major capsid protein). Esta proteína é altamente conservada nas espécies de Ranavirus, sendo frequente a reação sorológica cruzada devido a um alto nível de similaridade entre as estirpes deste gênero. Em geral, vírus dos diferentes gêneros possuem aproximadamente 50\% de similaridade dentro do gene MCP. Outros genes codificados por esses vírus são classificados em quatro categorias: genes diretamente envolvidos na replicação viral; genes envolvidos na evasão imune; genes homólogos aos de outros iridovírus e genes com nenhuma homologia conhecida (WILLIAMS; BARBOSA-SOLOMIEU; CHINCHAR, 2005; HOSSAIN et al., 2008). O diagnóstico laboratorial baseia-se nas técnicas moleculares e isolamento viral em cultivo celular, sendo este último o padrão-ouro recomendado pela OIE (CHINCHAR et al., 2005; GRAY et al., 2009; WHITTINGTON; BECKER; DENNIS, 2010). O isolamento viral deve ser confirmado por posterior ELISA ou PCR após o surgimento de efeito citopático característico em cultivo celular. Este consiste de lise focal rodeada por células granulosas arredondadas, as quais se estendem por toda a monocamada celular, que se solta e é desintegrada (OIE, 2012).

Em relação à replicação, estudos envolvendo FV3 indicam que ambas as populações de partículas envelopadas e não-envelopadas são infecciosas e podem ser isoladas em uma ampla gama de linhagens celulares (células de mamíferos, peixes, anfíbios e de répteis), enquanto que in vivo esta diversidade é bem menor e reflete a incapacidade do vírus de replicar em temperaturas acima de $32^{\circ} \mathrm{C}$, ou ainda em decorrência da possível falta de receptores celulares específicos, alterações na fisiologia celular e resposta imune (CHINCHAR et al., 2009).

Mesquita (2014) encontrou a presença de Ranavirus em exemplar de tilápia (Oreochromis niloticus) habitante dos arredores de ranário em Goiânia-GO com sintomatologia nervosa e positividade ao PCR em tempo real, indicando que existe a necessidade de monitoramento da disseminação do vírus entre outras espécies. Embora o isolamento de cepas de ranavírus de peixes e anfíbios indique que a transmissão entre classes seja possível, ainda é incerto se a transmissão entre classes taxonômicas é um evento comum. Tal fato pode explicar o aparecimento súbito de doença em populações anteriormente saudáveis (WILLIAMS; BARBOSA-SOLOMIEU; CHINCHAR, 2005). Ademais, o número de surtos de doenças atribuídas aos iridovírus tem aumentado 
acentuadamente, embora não seja claro se isso é devido a um aumento real na prevalência da doença ou ao aprimoramento técnico e de recursos humanos aplicados ao diagnóstico das infecções por iridovírus (WILLIAMS; BARBOSA-SOLOMIEU; CHINCHAR, 2005).

No Brasil, os relatos restringem-se a episódios de mortalidade em massa de girinos por FV3 em criações comerciais, no período de 2003 a 2005 em Goiás (MAZZONI et al., 2009); em 2006, numa investigação em criações brasileiras e uruguaias (GALLI et al., 2006) e em 2014, num estudo referente à síndrome vestibular em ranários de Goiás que revelou alta associação com a infecção por Ranavirus (MESQUITA, 2014). Recente estudo realizado por Almeida-Queiroz (2014) detectou Ranavirus em 100\% de 30 amostras pesquisadas por PCR em amostras de peixes coletadas durante eventos de mortalidade em tilapiculturas localizadas no Ceará e na Bahia, sendo o primeiro relato da ocorrência de infecções por Ranavirus em peixes de interesse zootécnico. 


\section{OBJETIVOS}

Em decorrência da necessidade de estudos envolvendo o isolamento e caracterização de ranavírus circulantes em anfíbios do interior do Estado de São Paulo, enfocando-se o diagnóstico laboratorial, empreendeu-se o presente projeto que teve como objetivos:

a. Realizar o isolamento viral em cultivo celular de estirpe circulante de Frog Virus 3-símile (Frog virus type 3) obtida de anfíbios da região nordeste do Estado de São Paulo;

b. Realizar a caracterização fenotípica e de cinética de replicação em cultivo celular do isolado viral obtido através da susceptibilidade a solvente de lipídeos, diluição limitante e curva de replicação. 


\section{MATERIAL E MÉTODOS}

\subsection{Cultivo de células}

Células BF-2 (bluegill fry ATCC ${ }^{\circledR}$ CCL- $91^{\circledR}$ ), gentilmente cedidas pelo Dr. John Kaufman (Department of Microbiology, Oregon State University, Oregon, EUA), foram mantidas e subcultivadas em MEM (minimum essential medium - Gibco ${ }^{\circledR}$, Life Technologies, EUA) suplementado com $10 \%$ de soro fetal bovino (SFB), $1 \%$ de LGlutamina, $100 \mathrm{UI} / \mathrm{mL}$ de penicilina e $100 \mu \mathrm{g} / \mathrm{mL}$ estreptomicina (PenStrep - Gibco ${ }^{\circledR}$, Life Technologies, EUA) sob incubação a $25^{\circ} \mathrm{C}$ e atmosfera com $5 \%$ de $\mathrm{CO}_{2}$. Concentrações variadas de 0,25 a $2,5 \mu \mathrm{g} / \mathrm{mL}$ de Fungizone ${ }^{\circledR}$ (Gibco ${ }^{\circledR}$, Life Technologies, EUA) foram testadas uma vez que as células não estavam totalmente adaptadas ao antifúngico.

\subsection{Amostras de tecido}

Oito amostras de fígado, baço e rins de rãs-touro gigante (Lithobates catesbeianus), positivas ao diagnóstico molecular para Ranavirus, confirmadas por sequenciamento nucleotídico, foram submetidas em pool ao isolamento viral em cultivo celular. Essas amostras foram coletadas de rãs-touro gigantes adultas provenientes de ranicultura comercial do interior do Estado de São Paulo, onde ocorreu surto de ranavirose em 2013, confirmado por diagnóstico molecular no Laboratório de Higiene Zootécnica da FZEA-USP. Essas amostras foram mantidas em freezer $-80^{\circ} \mathrm{C}$ até o processamento.

\subsection{Isolamento viral}

Para o isolamento viral, adotou-se o protocolo recomendado pela OIE (OIE, 2012) com algumas modificações.

Alíquotas de até 30mg de tecidos (pool) foram maceradas até sua total dissolução com o auxílio de cadinho, pistilo e areia estéril em $500 \mu \mathrm{L}$ de meio de inóculo composto por MEM (Gibco ${ }^{\circledR}$, Life Technologies, EUA), 2\% PenStrep (Gibco ${ }^{\circledR}$, Life Technologies, EUA) e $2 \mu \mathrm{g} / \mathrm{mL}$ de Fungizone $^{\circledR}$ (Gibco ${ }^{\circledR}$, Life Technologies, EUA). A solução foi centrifugada a $240 \times g$ por 5 minutos a $4^{\circ} \mathrm{C}$ para remover a areia e partículas grosseiras. O sobrenadante foi coletado e armazenado em microtubo estéril de $1,5 \mathrm{~mL}$ e mantido em gelo. Diluições de 1:10 e 1:100 desse material foram feitas para minimizar a contaminação do isolamento viral por fungos e bactérias e minimizar efeitos citotóxicos. 
Placas de 24 poços contendo monocamadas de $8 \times 10^{4}$ células BF-2 foram preparadas 48 horas anteriormente ao isolamento, mantidas em MEM (Gibco ${ }^{\circledR}$, Life Technologies, EUA) suplementado com 10\% soro fetal bovino (SFB), 1\% de L-Glutamina, 100UI/mL de penicilina, 100 $\mu \mathrm{g} / \mathrm{mL}$ estreptomicina (PenStrep - Gibco ${ }^{\circledR}$, Life Technologies, EUA) e $2 \mu \mathrm{g} / \mathrm{mL}$ de Fungizone ${ }^{\circledR}$ (Gibco ${ }^{\circledR}$, Life Technologies, EUA) e inoculadas com $100 \mu \mathrm{L}$ do inóculo de tecido macerado, sendo que para cada amostra foram utilizadas 3 alíquotas para inoculação, em duplicatas: não-diluída, 1:10 e 1:100. As monocamadas inoculadas foram incubadas em estufa a $25^{\circ} \mathrm{C}$ e $5 \%$ de $\mathrm{CO}_{2}$ durante uma hora para a fase de adsorção. Após o período de adsorção, o inóculo foi retirado e as monocamadas lavadas com PBS pH 7,2 $\left(\right.$ Gibco $^{\circledR}$, Life Technologies, EUA). Adicionou-se meio de manutenção composto por MEM (Gibco ${ }^{\circledR}$, Life Technologies, EUA) suplementado com 2\% de SFB, $1 \%$ de PenStrep (Gibco ${ }^{\circledR}$, Life Technologies, EUA), $2 \mu \mathrm{g} / \mathrm{mL}$ de Fungizone ${ }^{\circledR}$ (Gibco ${ }^{\circledR}$, Life Technologies, EUA) e 1\% de L-Glutamina. Como controle, meio de manutenção foi adicionado à monocamada sem inóculo. As placas contendo as monocamadas de células em meio de manutenção (P1) foram então incubadas a $25^{\circ} \mathrm{C}$ e $5 \%$ de $\mathrm{CO}_{2}$ durante seis dias e monitoradas para aparecimento de efeito citopático.

Após seis dias, as células inoculadas foram congeladas, em seguida descongeladas, e $500 \mu \mathrm{L}$ do sobrenadante de cada amostra foram inoculados em novas monocamadas de BF-2, com uma etapa de uma hora de adsorção. Adicionou-se meio de manutenção e esta passagem (P2) foi incubada a $25^{\circ} \mathrm{C}$ e $5 \%$ de $\mathrm{CO}_{2}$ e monitorada diariamente para efeito citopático.

Para a confirmação do isolamento viral, inoculou-se um frasco de $25 \mathrm{~cm}^{2}$ contendo monocamada de BF-2 com uma diluição de 1:4 do inóculo da passagem anterior ao efeito citopático, em MEM, com 1 hora de adsorção e posterior adição de meio de manutenção. Após o aparecimento de efeito citopático, as células foram removidas com cell scraper (Corning ${ }^{\circledR}$, Sigma-Aldrich Co., EUA), coletadas e centrifugadas por 5 min a $240 \times \mathrm{g}$ a $4^{\circ} \mathrm{C}$. O sobrenadante foi estocado em $-80^{\circ} \mathrm{C}$ e o sedimento de células utilizado para a extração de DNA.

Como controle negativo, um frasco de $25 \mathrm{~cm}^{2}$ contendo monocamada de BF-2 em meio de manutenção foi utilizado para extração de DNA. 


\subsection{Extração de DNA}

A extração foi realizada utilizando-se o kit QIAmp DNA Mini Kit (Qiagen, Alemanha), seguindo as instruções do fabricante. Ao final, o DNA foi eluído em $30 \mu \mathrm{L}$ de tampão AE e quantificado por espectrofotometria (DS-11, DeNovix, EUA), a fim de se evitar quantidades maiores que $250 \mathrm{ng} / \mu \mathrm{L}$ na reação de PCR, conforme indicação do kit comercial utilizado (item 4.5.2) e adotado para todas as reações realizadas.

\subsection{PCR e análise de polimorfismo no comprimento de fragmentos obtidos por digestão enzimática (RFLP) para confirmação do isolamento e identificação da estirpe viral.}

\subsubsection{Primers}

Os primers foram selecionados para a amplificação de fragmentos do gene MCP (nomeados como MCP1, MCP2 e MCP) de ranavírus de acordo com Marsh et al. (2002) e MAZZONI et al. (2009). As sequências dos primers utilizados, os respectivos tamanhos dos produtos amplificados, bem como os genes alvos correspondentes estão descritos na tabela 1.

Tabela 1 - Primers a serem utilizados nas reações de PCR para confirmação do isolamento de ranavírus.

\begin{tabular}{|c|c|c|c|c|}
\hline Nome & Orientação & Sequência (5’-3’) & Gene & $\begin{array}{c}\text { Produto } \\
\text { (pb) }\end{array}$ \\
\hline $\begin{array}{l}\text { M151 } \\
\text { M152 }\end{array}$ & $\begin{array}{l}\text { senso } \\
\text { antissenso }\end{array}$ & $\begin{array}{l}\text { AACCCGGCTTTCGGGCAGCA } \\
\text { CGGGGCGGGGTTGATGAGAT }\end{array}$ & $M C P-1$ & $321^{\mathrm{a}}$ \\
\hline $\begin{array}{l}\text { M153 } \\
\text { M154 }\end{array}$ & $\begin{array}{c}\text { senso } \\
\text { antissenso }\end{array}$ & $\begin{array}{l}\text { ATGACCGTCGCCCTCATCAC } \\
\text { CCATCGAGCCGTTCATGATG }\end{array}$ & MCP-2 & $625^{\mathrm{b}}$ \\
\hline $\begin{array}{l}\text { MCP-F } \\
\text { MCP-R }\end{array}$ & $\begin{array}{l}\text { senso } \\
\text { antissenso }\end{array}$ & $\begin{array}{l}\text { ATGTCTTCTGTAACTGGTTCA } \\
\text { AAAGACCCGTTTTGCAGCAAAC }\end{array}$ & $M C P$ & $1483^{c}$ \\
\hline
\end{tabular}

\subsubsection{PCR}

Para as reações de PCR, utilizou-se o kit GoTaq ${ }^{\circledR}$ Colorless Mastermix 2X (PROMEGA, EUA), seguindo as instruções do fabricante. Em síntese, $1 \mu \mathrm{L}$ do DNA extraído das células BF-2 foi misturado com 12,5 $\mu \mathrm{L}$ de GoTaq ${ }^{\circledR}$ Colorless Mastermix 2X, 
$1 \mu \mathrm{L}$ do primer senso específico (M151, M153 ou MCP-F) a 10 $\mu \mathrm{M}, 1 \mu \mathrm{L}$ do primer antissenso específico (M152, M154 ou MCP-R) a 10 $\mu \mathrm{M}$ e 9,5 $\mu \mathrm{L}$ de água livre de nucleases, totalizando $25 \mu \mathrm{L}$.

O protocolo de termociclagem empregado (Swift ${ }^{\mathrm{TM}}$ MaxPro Thermal Cycler, Esco Technologies Inc., EUA) para ambas as reações visando a amplificação dos fragmentos MCP1 e MCP2 compreendeu: incubação inicial a $94^{\circ} \mathrm{C}$ por $3 \mathrm{~min}$, e, em seguida, 35 ciclos de $94^{\circ} \mathrm{C}$ por 30 segundos, anelamento a $50^{\circ} \mathrm{C}$ por 30 segundos e extensão a $72^{\circ} \mathrm{C}$ por 1 minuto, com uma extensão final a $72^{\circ} \mathrm{C}$ por 5 minutos, conforme recomendações da (OIE, 2012). O protocolo de termociclagem para a amplificação do fragmento completo do gene MCP, como recomendado por Mazzoni et al. (2009) compreendeu uma incubação inicial a $90^{\circ} \mathrm{C}$ por 1 minuto, seguido de 40 ciclos de $94^{\circ} \mathrm{C}$ por 1 minuto, $60^{\circ} \mathrm{C}$ por 1 minuto, $72^{\circ} \mathrm{C}$ por 90 segundos e uma extensão final a $72^{\circ} \mathrm{C}$ por 5 minutos.

Os amplicons obtidos foram submetidos à eletroforese em gel de agarose a $1 \%$ em tampão Tris-Acetato/EDTA (TAE 1X), num volume de $8 \mu \mathrm{L}$ por amostra, adicionados de um volume de $2 \mu \mathrm{L}$ de Blue/Orange Loading Dye (PROMEGA, EUA). Na sequência, o gel foi submetido à coloração em solução de $S Y B R^{\circledR}$ Gold nucleic acid gel stain (Thermo Fisher, Life Technologies, EUA). Em seguida, o gel foi observado à luz UV, utilizando-se sistema de fotodocumentação L-Pix ST e software L-Pix Image (Loccus Biotecnologia, Brasil). O tamanho dos amplicons foi determinado pela comparação do padrão de migração eletroforética de um marcador de peso molecular de 100pb (100bp DNA Ladder, PROMEGA, EUA).

\subsubsection{Análise de polimorfismo no comprimento de fragmentos obtidos por digestão enzimática (RFLP)}

Os produtos de PCR obtidos pela amplificação dos fragmentos MCP1 e MCP2 do gene MCP de Ranavirus, quando analisados por RFLP podem ser diferenciados entre os ranavírus causadores de doença em peixes (Vírus da Necrose Hematopoética Epizoótica EHNV, Vírus do bagre europeu - ECV) e os ranavírus patogênicos de anfíbios (Frog Virus 3 - FV3, Bohle iridovirus - BIV) (MARSH et al., 2002).

Para isso, os fragmentos MCP1 e MCP2 foram submetidos à RFLP: os amplicons obtidos na amplificação do fragmento MCP1 foram digeridos pela enzima PflM I, enquanto que os amplicons MCP-2 foram digeridos pelas enzimas Hinc II, Acc I e 
Fnu4H I (separadamente) para identificação do ranavírus isolado, segundo MARSH et al (2002). Os padrões esperados para cada vírus estão descritos na tabela 2.

Tabela 2 - Análise de polimorfismo no comprimento de fragmentos obtidos por digestão enzimática dos amplicons do gene MCP obtidos por PCR.

\begin{tabular}{|c|c|c|c|}
\hline Reação de PCR & $\begin{array}{l}\text { Enzima de } \\
\text { restrição }\end{array}$ & $\begin{array}{c}\text { Bandas esperadas após } \\
\text { digestão (pb) }\end{array}$ & Padrão esperado em \\
\hline \multirow[t]{2}{*}{ MCP1 (321pb) } & \multirow[t]{2}{*}{ PflM I } & 321 & EHNV, BIV \\
\hline & & 131,190 & FV3, WIV \\
\hline \multirow[t]{11}{*}{ MCP2 (625pb) } & \multirow[t]{3}{*}{ Hinc II } & $100,138,387$ & EHNV \\
\hline & & 100,525 & $\mathrm{BIV}, \mathrm{FV3}$ \\
\hline & & $100,240,285$ & WIV \\
\hline & \multirow[t]{3}{*}{ Acc I } & 238,387 & EHNV \\
\hline & & 625 & BIV, ESV, ECV, WIV \\
\hline & & 164,461 & FV3, GV \\
\hline & \multirow[t]{5}{*}{ Fnu4H I } & $33,38,44,239,271$ & EHNV \\
\hline & & $3,33,38,44,108,399$ & BIV \\
\hline & & $3,38,44,108,432$ & FV3, GV \\
\hline & & $3,9,38,44,108,151,272$ & ESV, ECV \\
\hline & & $3,44,71,108,399$ & WIV \\
\hline
\end{tabular}

Fonte: MARSH et al (2002)

Em linhas gerais, $5 \mu \mathrm{L}$ do produto da PCR (MCP1 ou MCP2) foram misturados com 0,5 $\mu \mathrm{L}$ da respectiva enzima (PflM I ou Hinc II ou Acc I ou Fnu4H I), 2,5 $\mu \mathrm{L}$ de seu tampão (10X NE Buffer para PfIM I, Tango buffer para Hinc II e 10X NEB buffer para Acc I e Fnu4H I, New England BioLabs, EUA) e $17 \mu \mathrm{L}$ de água livre de nucleases, totalizando $25 \mu \mathrm{L}$. Para a digestão por Hinc II, foi necessária a adição de 2,5 $\mu \mathrm{L}$ de albumina sérica bovina e, portanto, somente $14,5 \mu \mathrm{L}$ de água, também totalizando $25 \mu \mathrm{L}$. A digestão do fragmento MCP1 por PflM I e do MCP2 por Hinc II compreendeu incubação por 2 horas a $37^{\circ} \mathrm{C}$ e inativação por 20 minutos a $65^{\circ} \mathrm{C}$. A digestão do fragmento $\mathrm{MCP} 2$ por Acc I compreendeu 2 horas a $37^{\circ} \mathrm{C}$ e inativação por 20 minutos a $80^{\circ}$, enquanto a digestão por Fnu4H I compreendeu 2 horas a $37^{\circ} \mathrm{C}$.

Os produtos digeridos foram submetidos à eletroforese em gel de agarose a 3\% em tampão Tris-Acetato/EDTA (TAE 1X), sendo aplicados os $25 \mu \mathrm{L}$, adicionados de $5 \mu \mathrm{L}$ de Blue/Orange Loading Dye (PROMEGA, EUA). Na sequência, o gel foi submetido à coloração em solução de $S Y B R^{\circledR}$ Gold Nucleic Acid Gel Stain (Thermo Fisher, Life Technologies, EUA) e foi observado à luz UV, utilizando-se sistema de fotodocumentação L-Pix ST e software L-Pix Image (Loccus Biotecnologia, Brasil) para visualização dos padrões de polimorfismo no comprimento de fragmentos obtidos. 


\subsection{Sequenciamento nucleotídico}

A extração dos fragmentos de DNA dos géis de agarose, após reamplificação pelo PCR anteriormente descrito (item 3.5.2) para o gene MCP, foi realizada utilizando-se o kit QIAquick PCR Purification Kit (Qiagen, Alemanha), segundo as recomendações do fabricante.

A reação de sequenciamento incluiu o BigDye ${ }^{\circledR}$ Terminator v3.1 Cycle Sequencing Ready Reaction Kit (Applied Biosystems, Life Technologies, EUA), contendo AmpliTaq DNA Polymerase, de acordo com as especificações do fabricante, e dos primers senso e antissenso. As reações foram preparadas em microplaca de 96 cavidades (MicroAmp Optical 96 wells, Applied Biosystems, Life Technologies, EUA) e o sequenciamento foi realizado num seqüenciador automático Applied Biosystems 3730 DNA Analyzer (Applied Biosystems, Life Technologies, EUA) pelo Setor de Sequencimento de DNA do Centro de Estudos do Genoma Humano da Universidade de São Paulo.

A busca de similaridade das seqüências geradas e editadas com o programa BioEdit 7.0.9 (HALL et al., 1999) foi realizada pelo programa BLAST versão 2.0 (ALTSCHUL et al., 1997). A edição e alinhamento múltiplo das seqüências nucleotídicas e deduzidas de aminoácidos obtidas foram realizadas com o programa ClustalW versão 1.4 (THOMPSON et al., 1994), implementado no programa BioEdit Sequence Alignment Editor versão 7.0.2 (HALL et al., 1999), utilizando-se, para tanto, dos parâmetros em 'default' e sequência homóloga da estirpe de referência Frog Virus 3 (número de acesso GenBank: KJ175144) depositada no GenBank. A visualização do alinhamento foi realizada através do programa Jalview versão 2.8.1 (WATERHOUSE et al., 2009).

\subsection{Microscopia Eletrônica de Transmissão}

Após a confirmação do isolamento por PCR-RFLP, a amostra foi submetida à microscopia eletrônica de transmissão para caracterização da morfologia viral. Um frasco de $25 \mathrm{~cm}^{2}$ contendo monocamada de células BF-2 foi inoculado com $10 \mu \mathrm{L}$ do sobrenadante da terceira passagem diluído em $990 \mu \mathrm{L}$ de MEM, por uma hora de incubação a $25^{\circ} \mathrm{C}$ a $5 \%$ de $\mathrm{CO}_{2}$. Foram adicionados $4 \mathrm{~mL}$ de meio de manutenção como descrito no item 3.3 e realizado monitoramento diário para aparecimento de efeito citopático, o qual ocorreu após 24h. O meio foi removido e as células removidas com cell scraper (Corning ${ }^{\circledR}$, SigmaAldrich Co., EUA) e fixadas em solução de glutaraldeído a 2\%, e, em seguida, fixadas em 
solução de tetróxido de ósmio a $2 \%$ e uranila $0,5 \%$ overnight. Na sequência, a amostra fixada foi desidratada duas vezes por 10 minutos em álcool 70\%, duas vezes em álcool a 95\% por 10 minutos, 4 vezes em álcool 100\% por 10 minutos e duas vezes em óxido de propileno por 10 minutos. Após a desidratação, a amostra foi submetida à mistura de óxido de propileno em conjunto com resina Spurr por 6 horas e em resina pura por mais 6 horas. Posteriormente, foi realizada incubação em estufa a $72^{\circ} \mathrm{C}$ por $48 \mathrm{~h}$ e, depois, o bloco foi submetido a cortes ultrafinos de 70 a $80 \mathrm{~nm}$, contrastados com chumbo e uranila, sendo visualizados em microscópio eletrônico de transmissão (JEM-1010, JEOL, Japão) do Instituto de Ciências Biomédicas da Universidade de São Paulo.

\subsection{Determinação do título viral $\left(\right.$ TCID $\left._{50}\right)$}

Placas de 96 poços contendo monocamadas de $1,5 \times 10^{4}$ células BF-2 foram preparadas 24 horas anteriores à titulação e mantidas em MEM (Gibco ${ }^{\circledR}$, Life Technologies, EUA) suplementado com $10 \%$ de soro fetal bovino (SFB), $1 \%$ de LGlutamina, $100 \mathrm{UI} / \mathrm{mL}$ de penicilina, $100 \mu \mathrm{g} / \mathrm{mL}$ estreptomicina (PenStrep - Gibco ${ }^{\circledR}$, Life Technologies, EUA) e $2 \mu \mathrm{g} / \mathrm{mL}$ de Fungizone $^{\circledR}$ (Gibco ${ }^{\circledR}$, Life Technologies, EUA). Diluições do inóculo viral inicial foram feitas de $10^{-1}$ a $10^{-8}$ a partir da passagem que demonstrou efeito citopático. Cada poço contendo monocamada de células foi inoculado com $50 \mu \mathrm{L}$ de cada diluição, sendo realizada em oito réplicas. As monocamadas inoculadas foram incubadas em estufa a $25^{\circ} \mathrm{C}$ e $5 \%$ de $\mathrm{CO}_{2}$ durante uma hora para a adsorção das partículas virais. Após o período de adsorção, foram adicionados $50 \mu \mathrm{L}$ de meio de manutenção composto por MEM (Gibco ${ }^{\circledR}$, Life Technologies, EUA) suplementado com $2 \%$ de SFB, $1 \%$ de PenStrep (Gibco ${ }^{\circledR}$, Life Technologies, EUA), $2 \mu \mathrm{g} / \mathrm{mL}$ de Fungizone ${ }^{\circledR}$ $\left(\right.$ Gibco $^{\circledR}$, Life Technologies, EUA) e 1\% de L-Glutamina em cada poço. Como controle negativo, foi adicionado meio de manutenção à monocamada sem inóculo viral. As placas contendo as monocamadas de células em meio de manutenção foram então incubadas a $25^{\circ} \mathrm{C}$ e $5 \%$ de $\mathrm{CO}_{2}$ e a leitura foi realizada no sexto dia de incubação. A TCID 50 foi então calculada de acordo com Reed e Muench (1938).

\subsection{Susceptibilidade a solvente de lipídeos}

O teste de susceptibilidade a solvente de lipídeos foi realizado de acordo com Speare e Smith (1992). Adidionou-se 0,5mL de éter a $1 \mathrm{~mL}$ do inóculo contendo vírus. Como controle negativo, $0,5 \mathrm{~mL}$ de éter foi adicionado a $1 \mathrm{~mL}$ de MEM. As soluções foram 
homogeneizadas e incubadas overnight a $4^{\circ} \mathrm{C}$ e tituladas em duplicatas conforme protocolo descrito no ítem 4.8 .

\subsection{Curva de Replicação}

Placas de 24 poços contendo monocamadas de $8 \times 10^{4}$ células BF-2 foram preparadas com 24 horas de antecedência, mantidas em MEM (Gibco ${ }^{\circledR}$, Life Technologies, EUA) suplementado com 10\% de soro fetal bovino (SFB), 1\% de L-Glutamina, 100UI/mL de penicilina, $100 \mu \mathrm{g} / \mathrm{mL}$ de estreptomicina (PenStrep - Gibco ${ }^{\circledR}$, Life Technologies, EUA) e $2 \mu \mathrm{g} / \mathrm{mL}$ de Fungizone ${ }^{\circledR}$ (Gibco ${ }^{\circledR}$, Life Technologies, EUA). Seis poços (dois para cada dia - duplicata) foram infectados com $100 \mu \mathrm{L}$ do inóculo viral da quinta passagem da amostra isolada (P5-154RV, 10,8 TCID $_{50} / \mathrm{mL}$ ) diluído em $900 \mu \mathrm{L}$ de meio de manutenção composto por MEM (Gibco $^{\circledR}$, Life Technologies, EUA) suplementado com $2 \%$ de SFB, 1\% de PenStrep $\left(\right.$ Gibco $^{\circledR}$, Life Technologies, EUA), $2 \mu \mathrm{g} / \mathrm{mL}$ de Fungizone ${ }^{\circledR}$ (Gibco ${ }^{\circledR}$, Life Technologies, EUA), 1\% de L-Glutamina. As monocamadas infectadas foram incubadas em estufa a $25^{\circ} \mathrm{C}$ e $5 \%$ de $\mathrm{CO}_{2}$ durante uma hora para a adsorção das partículas virais e após esta etapa, $900 \mu \mathrm{L}$ de meio de manutenção foram adicionados a cada poço. Como controle negativo foi usado meio de manutenção sem inóculo. Células e meio de cultivo foram coletadas diariamente (24h, 48h, 72h, 96h, 120h e 144h pós inoculação) e mantidas a $-80^{\circ} \mathrm{C}$. Estas alíquotas foram então descongeladas e tituladas, com o protocolo descrito no item 4.8, realizado em duplicatas. 


\section{RESULTADOS}

\subsection{Cultivo celular}

Monocamadas de BF-2 foram cultivadas e subcultivadas em MEM (minimum essential medium - Gibco ${ }^{\circledR}$, Life Technologies, EUA) suplementado com $10 \%$ de soro fetal bovino (SFB), $1 \%$ de L-Glutamina, 100UI/mL de penicilina e $100 \mu \mathrm{g} / \mathrm{mL}$ de estreptomicina $\left(\right.$ PenStrep - Gibco ${ }^{\circledR}$ ) sob incubação a $25^{\circ} \mathrm{C}$ e atmosfera de $5 \%$ de $\mathrm{CO}_{2}$. Foi necessária a adaptação progressiva das células a concentrações superiores a $0,25 \mu \mathrm{g} / \mathrm{mL}$ de anfotericina B (Fungizone ${ }^{\circledR}$, Gibco ${ }^{\circledR}$ Life Technologies, EUA), visto que o emprego direto de $2 \mu \mathrm{g} / \mathrm{mL}$, como proposto inicialmente, causou a perda das células viáveis. Desta forma, iniciou-se o cultivo com uma concentração de $0,25 \mu \mathrm{g} / \mathrm{mL}$, aumentando gradativamente esta concentração em $0,25 \mu \mathrm{g}$ a cada repique, alcançando uma concentração final de $2 \mu \mathrm{g} / \mathrm{mL}$.

Figura 8 - Monocamada de células BF-2 em adaptação gradual a concentrações de Fungizone ${ }^{\circledR}$.

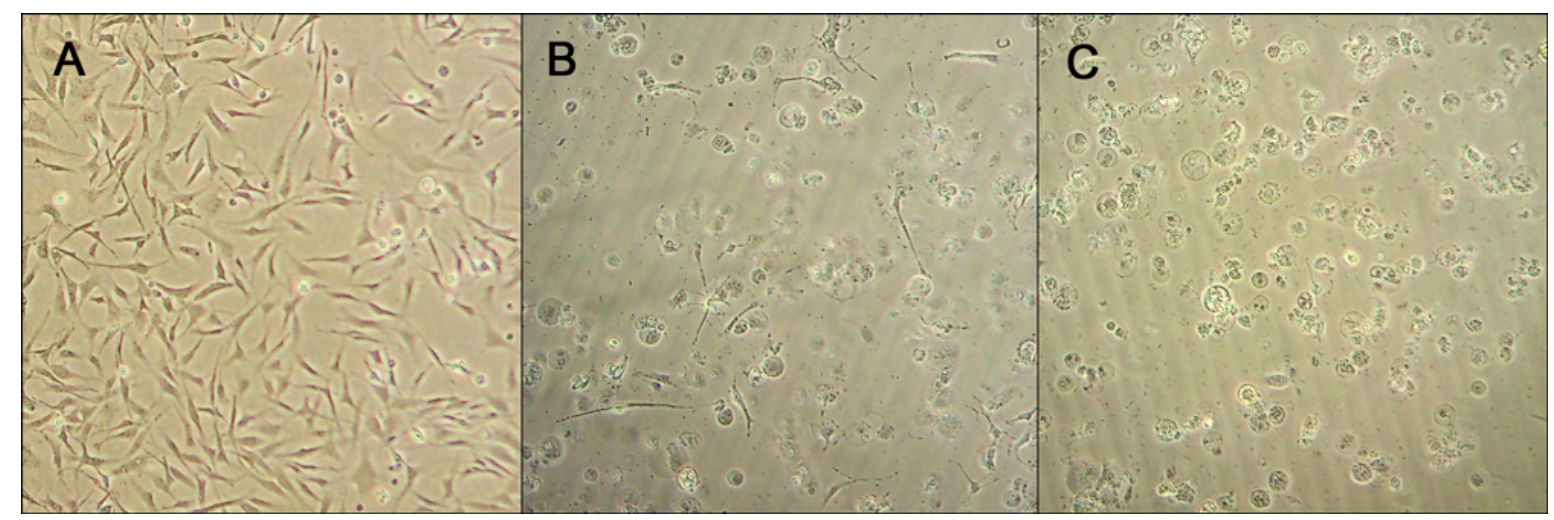

Legenda: A- Controle, sem Fungizone ${ }^{\circledR}$; B-Células com $1 \mu \mathrm{g} / \mathrm{mL}$ de Fungizone $^{\circledR}$; C - Células com $2 \mu \mathrm{g} / \mathrm{mL}$ de Fungizone ${ }^{\circledR}\left(\right.$ Gibco $^{\circledR}$, Life Technologies, EUA).

Fonte: Própria autoria.

\subsection{Isolamento viral}

Das oito amostras submetidas ao isolamento viral, somente duas (151 e 154) apresentaram efeito citopático característico de ranavírus, caracterizado por arredondamento celular, lise e desprendimento da monocamada com morte celular (Figuras 10, 11 e 12). O efeito citopático iniciou ao final da segunda passagem (P2) (Figura 9). Foram feitas novas passagens a fim de se aumentar a carga viral para todos os ensaios de caracterização. Os estudos descritos nesta dissertação foram realizados a partir da quinta passagem da amostra 154 . 
Figura 9 - Células inoculadas com a segunda passagem (P2) da amostra 154 utilizadas na extração de DNA.

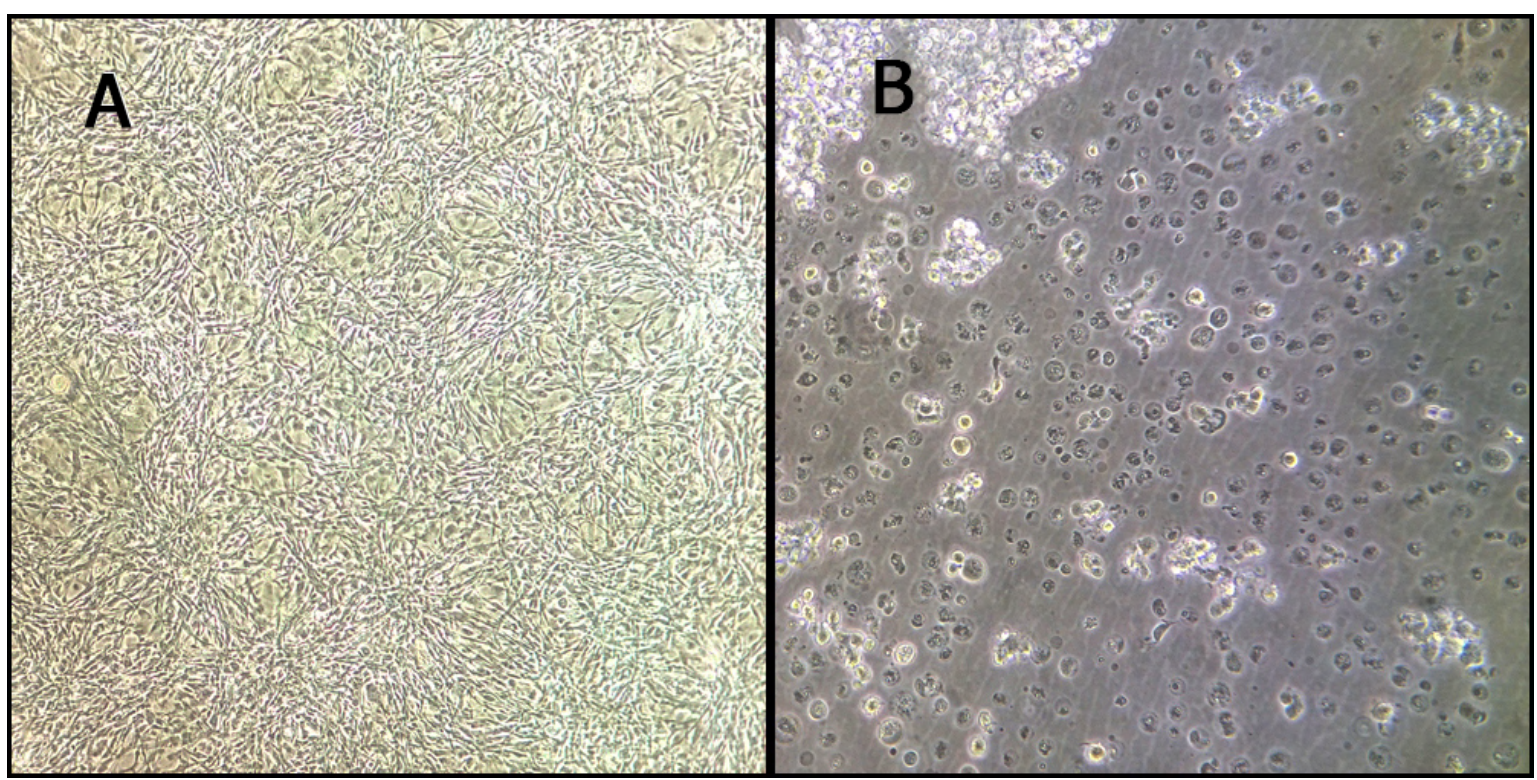

Legenda: A: Controle: Monocamada de células BF-2 em meio de manutenção. Aumento de 400X. B: Monocamada de células BF-2 inoculadas com P2 da amostra 154 diluída em MEM, mostrando destruição completa da monocamada, com destacamento, arredondamento e morte celular em 24h. Aumento de 400X.

Fonte: Própria autoria.

Figura 10 - Efeito citopático de ranavírus em monocamada de BF-2 inoculada com a amostra 154 na passagem 1 (P1).

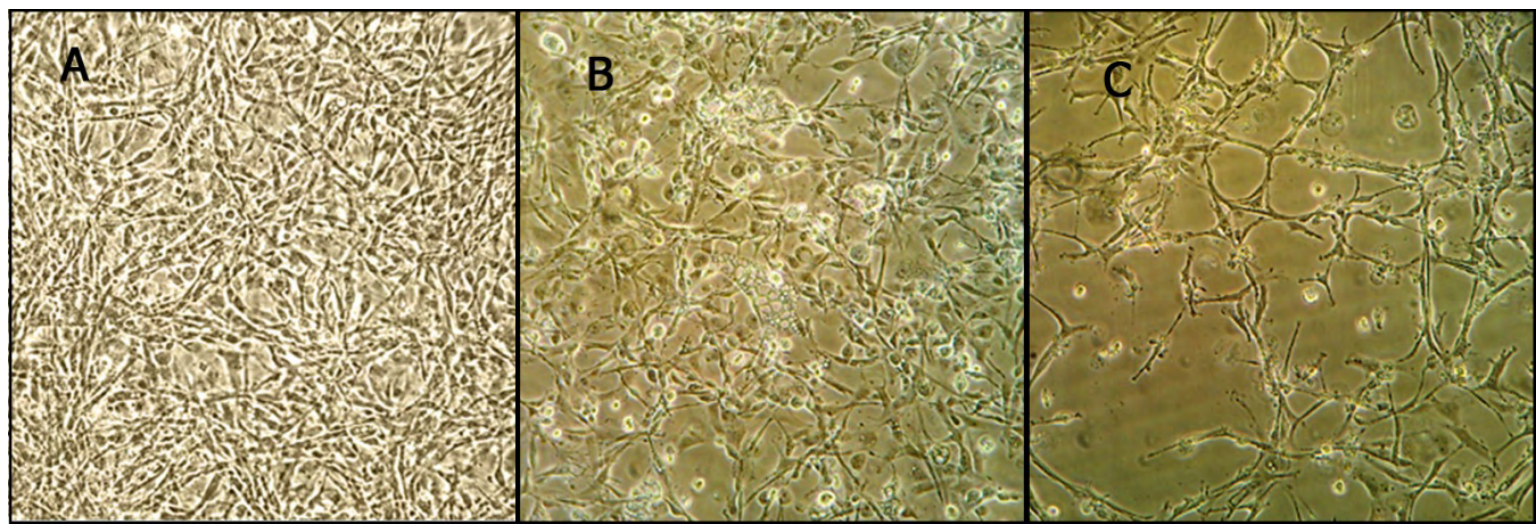

Legenda: A: Controle - Monocamada de células BF-2 em meio de manutenção. B: Monocamada de células BF-2 um dia após inoculação (1dpi) da amostra 154 na diluição 1:100. C: Monocamada de células BF-2 três dias após inoculação (3dpi) da amostra 154 na diluição 1:100 (Aumento de 200x).

Fonte: Própria autoria. 
Figura 11 - Efeito citopático de ranavírus em monocamada de BF-2 inoculada com a amostra 154 na segunda passagem (P2).

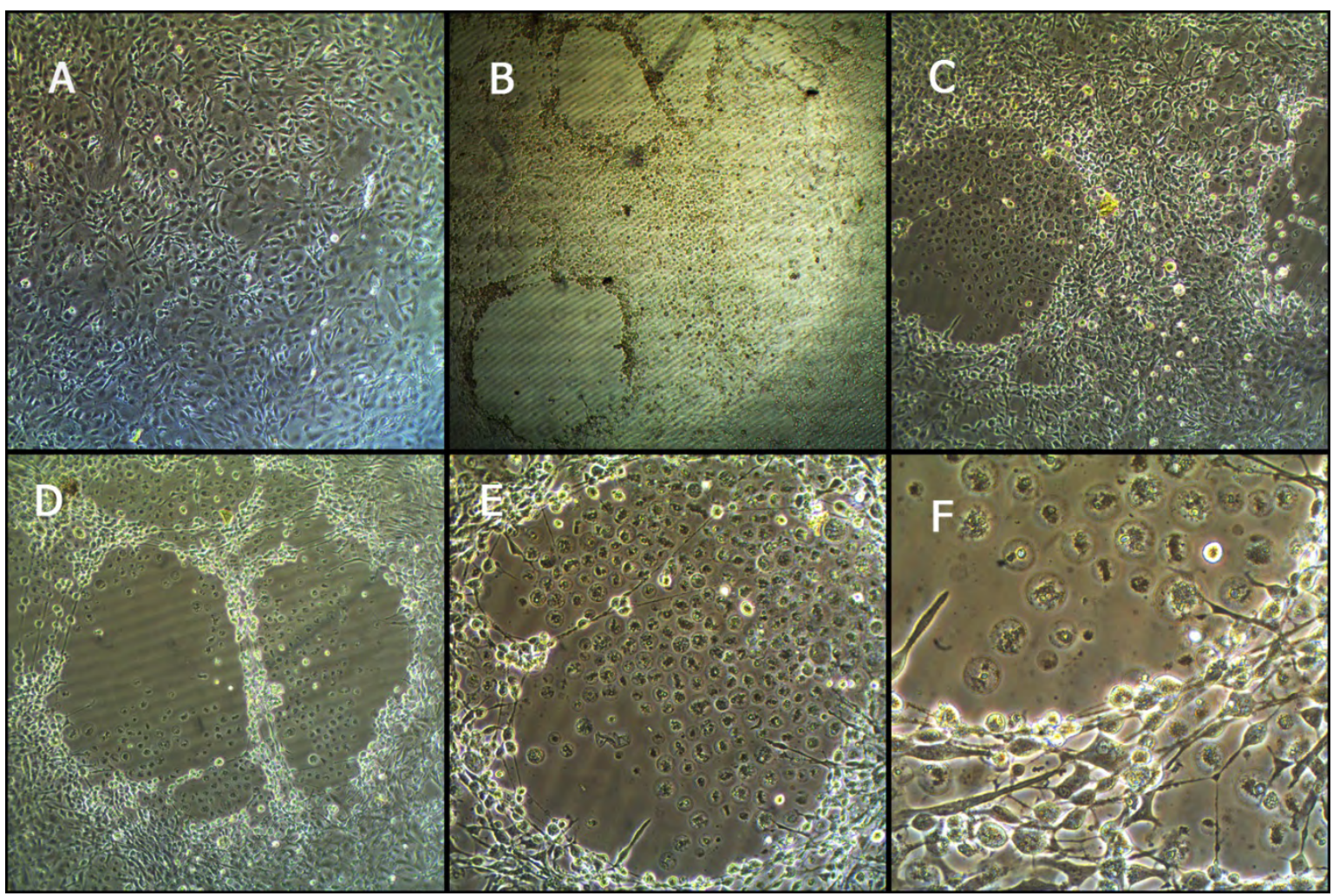

Legenda: A: Controle negativo - monocamada de células BF-2 em meio de manutenção. Aumento de 40X; B: Células BF-2 inoculadas com a amostra 154 na diluição 1:10 em MEM mantidas com meio de manutenção por seis dias. Evidências de lise focal da monocamada. Aumento de 100X. C, D, E: Células BF-2 inoculadas com amostra 154 na diluição 1:100 em MEM mantidas com meio de manutenção por seis dias. Evidência de áreas com lise focal da monocamada e morte celular. C e D - Aumento de 100X, E - Aumento de 200X; F: Células BF-2 inoculadas com a amostra 154 na diluição 1:100 em MEM mantidas com meio de manutenção por seis dias. Detalhe aumentado evidenciando arrendondamento celular, com destruição da monocamada e morte celular. Aumento de 400X.

Fonte: Própria autoria. 
Figura 12 - Efeito citopático de ranavírus em monocamada de BF-2 inoculada com a amostra 151 na segunda passagem (P2), no sexto dia após inoculação.

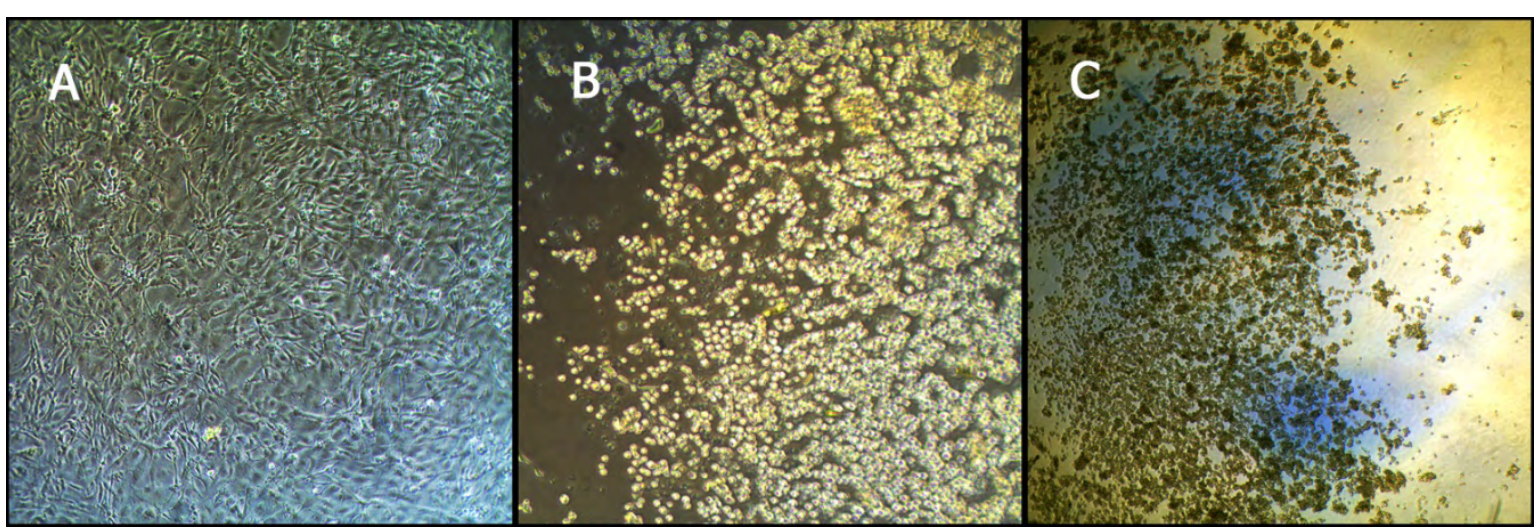

Legenda: A: Controle, monocamada de células BF-2 em meio de manutenção. Aumento de 100X; B: Células BF-2 inoculadas com amostra 151 na diluição 1:10 em MEM mantidas com meio de manutenção mostrando destruição da monocamada com morte celular em sua totalidade. C: Células BF-2 inoculadas com amostra 151 na diluição 1:100 em MEM mantidas com meio de manutenção, exibindo destruição da monocamada com morte celular em sua totalidade.

Fonte: Própria autoria.

\subsection{PCR e análise de polimorfismo no comprimento de fragmentos obtidos por digestão enzimática (RFLP) para confirmação do isolamento e identificação da estirpe viral}

A confirmação do isolamento foi feita por PCR. O isolamento foi confirmado, sendo que foram obtidos amplicons de tamanhos esperados para o gene MCP e todos os fragmentos pesquisados: MCP1, MCP2 e MCP (Figuras 13 e 14).

As RFLPs dos fragmentos MCP-1 e MCP-2 revelaram um padrão compatível com Frog Virus 3 (Figura 15). 
Figura 13 - Fotografia de gel de agarose a 1,5\% corado com SYBR ${ }^{\circledR}$ Gold, sob luz UV, ilustrando resultados de amplificação por PCR dos fragmentos MCP1 (321pb) e MCP2 (625pb) da proteína principal do capsídeo de ranavírus (MCP), a partir de DNA extraído da $2^{\mathrm{a}}$ passagem da amostra 154 em células BF-2.

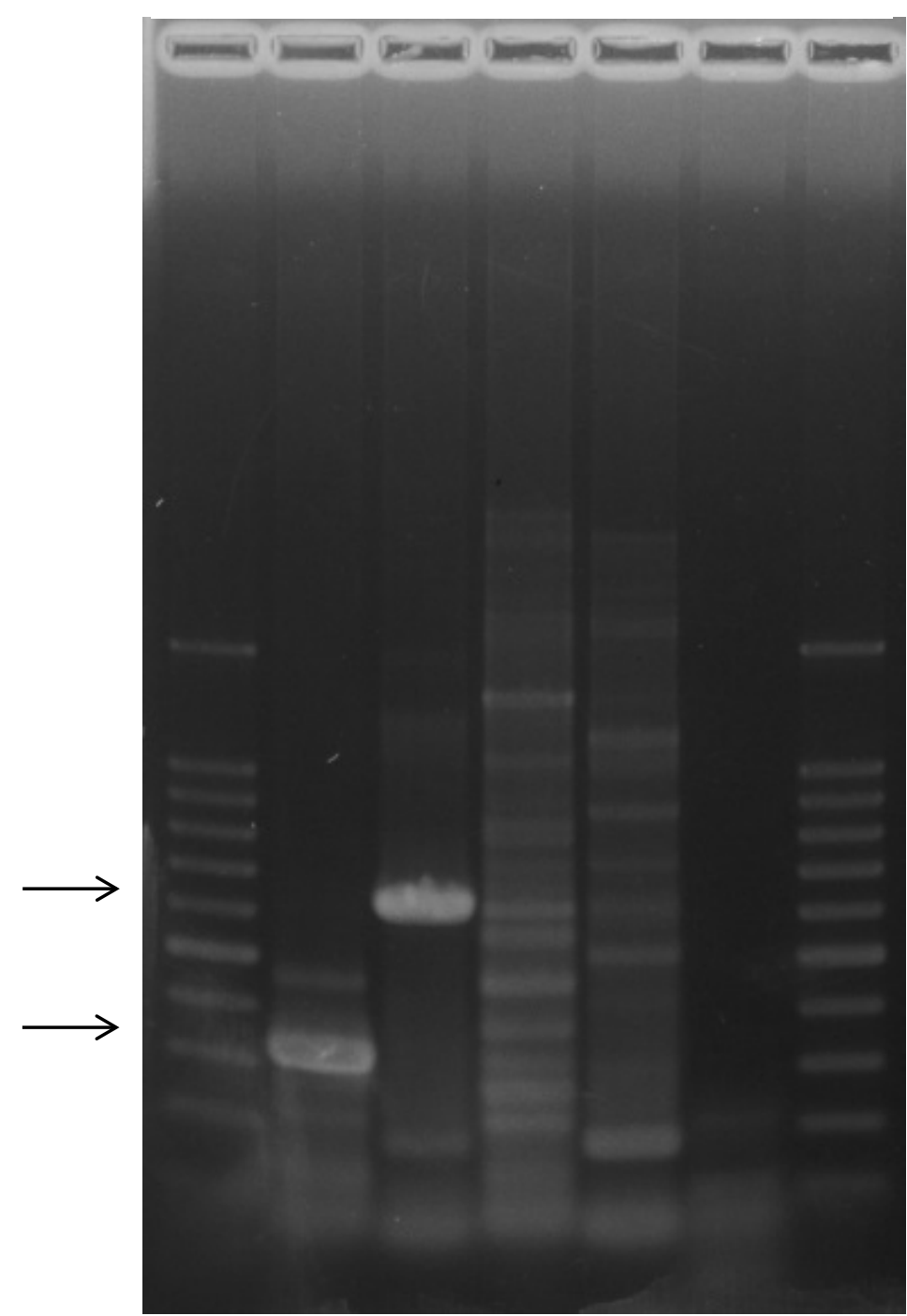

Legenda: (1 e 7) Marcador de peso molecular de 100pb (PROMEGA, EUA). (2) PCR da amostra 154 para o fragmento MCP1. (3) PCR da amostra 154 para o fragmento MCP2. (4) PCR do controle negativo de células para o gene MCP1. (5) PCR do controle negativo de células para o gene MCP2. (6) $\mathrm{H}_{2} \mathrm{O}$ livre de nucleases.

Fonte: Própria autoria. 
Figura 14 - Fotografia de gel de agarose a 1,5\% corado com SYBR ${ }^{\circledR}$ Gold, sob luz UV, ilustrando resultados de amplificação completa por PCR do gene MCP (1483pb) de ranavírus, a partir de DNA extraído da $2^{\mathrm{a}}$ passagem da amostra 154 em células BF-2.

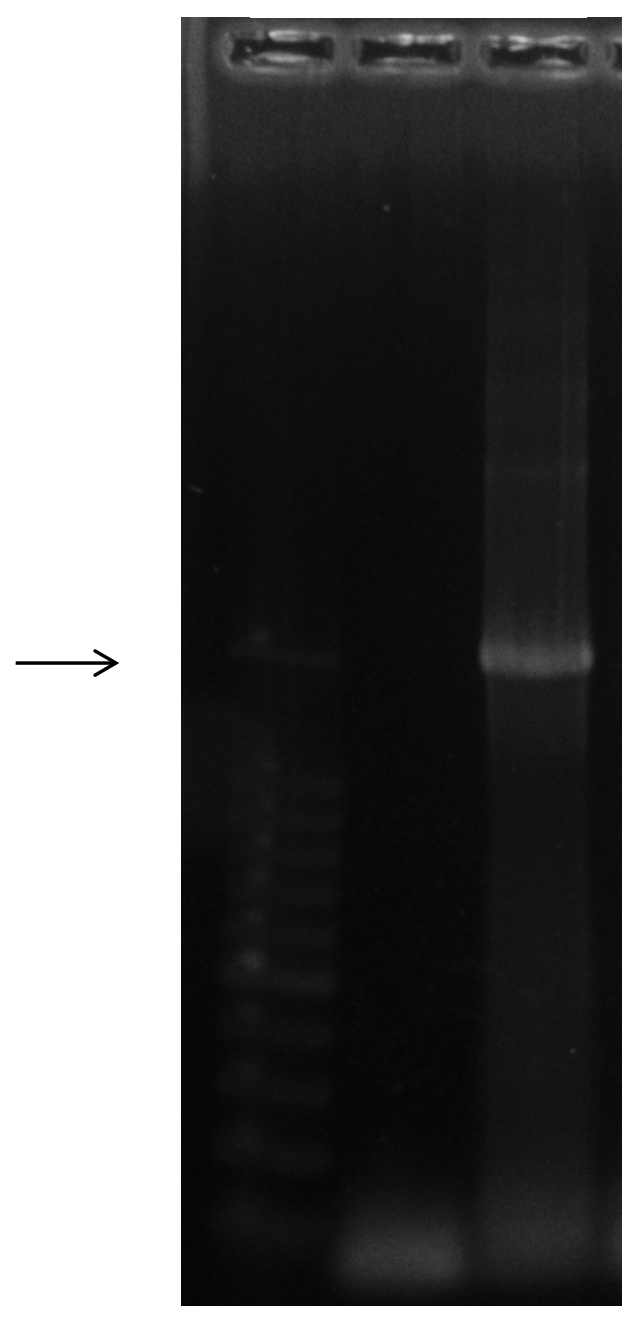

Legenda: (1) Marcador de peso molecular de 100pb. (PROMEGA, EUA) (2) $\mathrm{H}_{2} \mathrm{O}$ livre de nucleases. (3) P2 da amostra 154.

Fonte: Própria autoria. 
Figura 15 - Fotografia de gel de agarose a 3,0\% corado com SYBR ${ }^{\circledR}$ Gold, sob luz UV, ilustrando resultados de digestão por enzimas de restrição dos fragmentos MCP1 e MCP2 obtidos para a amostra 154.

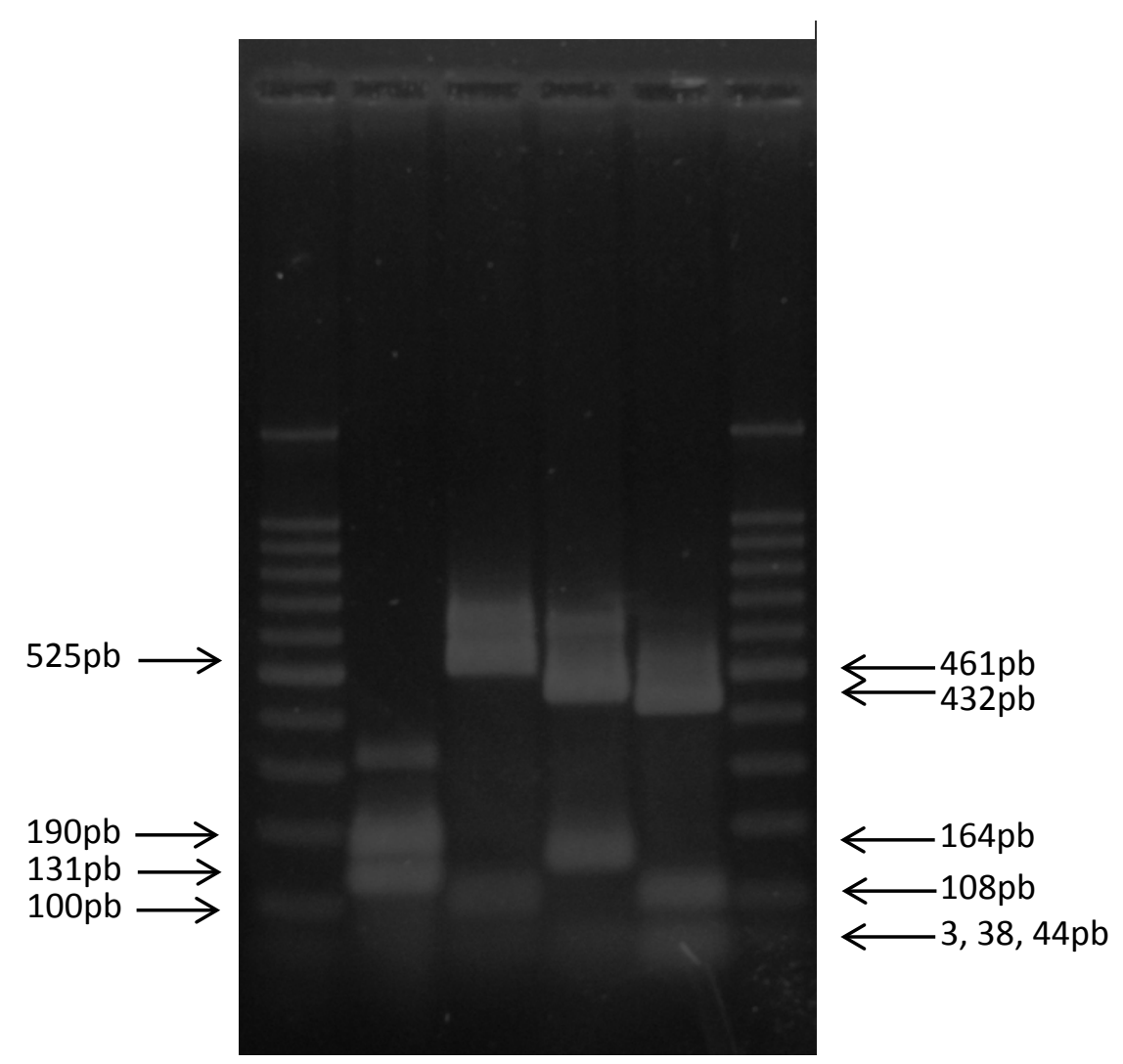

Legenda: (1) Marcador de 100pb. (2) MCP1 PfIM I. (3) MCP2 Hinc II. (4) MCP2 Acc I. (5) MCP2 Fnu4H I. (6) Marcador de 100pb (PROMEGA, EUA).

Fonte: Própria autoria.

\subsection{Sequenciamento nucleotídico}

O sequenciamento nucleotídico de fragmento com aproximadamente 1.483pb, correspondente ao gene MCP de ranavírus da amostra 154, e posterior comparação da similaridade da sequência derivada com sequências homólogas, levaram a confirmação do produto obtido como fragmento genômico do ranavírus Frog Virus 3. Na busca de similaridade através do BLAST, a sequência obtida apresentou valor $\mathrm{E}=0$ com genoma completo de Frog Virus 3, recuperada do GenBank (número de acesso: KJ175144), indicando probabilidade desconsiderável de alinhamento ao acaso, e valor de identidade de 96\%. A figura 16 ilustra o alinhamento das sequências de aminoácidos deduzidos entre Amostra\#154 e Frog Virus 3 para cerca de 330 aminoácidos de MCP. 
Figura 16 - Alinhamento entre as sequências deduzidas de aminoácidos do gene MCP de ranavírus para as amostras 154 e Frog Virus 3 (número de acesso GenBank: KJ175144).

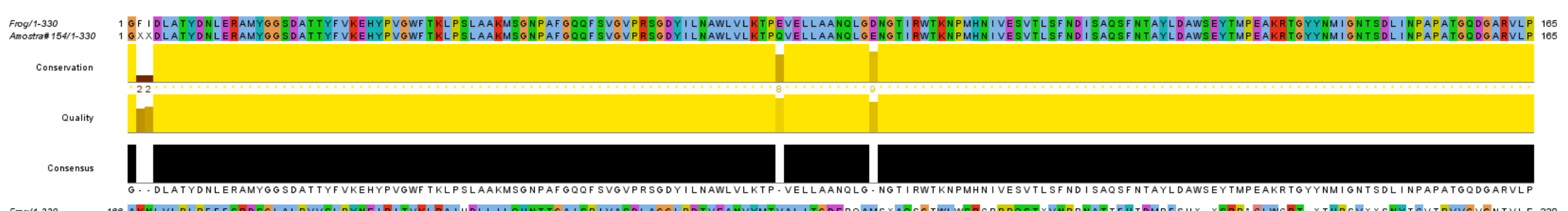

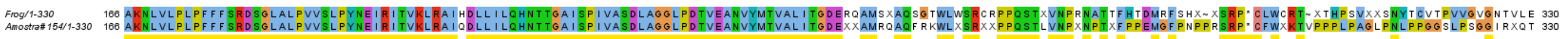

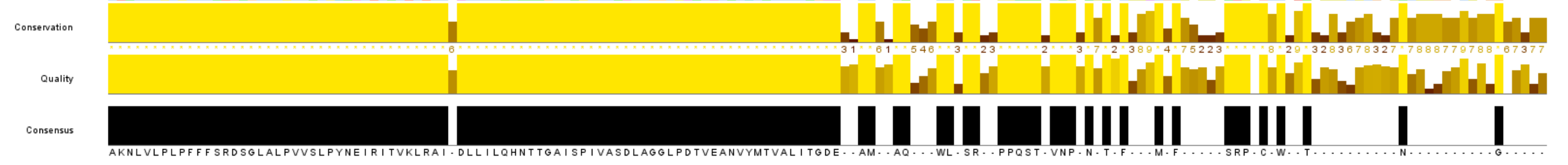

Legenda: O histograma Conservation reflete a conservação das propriedades físico-químicas dos aminoácidos e indica resíduos completamente conservados com um asterisco amarelo, sendo as posições menos conservadas mostradas em cores mais escuras. O histograma de qualidade de anotação Quality reflete a probabilidade de se observar uma mutação numa coluna qualquer do alinhamento baseada nos escores da matriz BLOSUM62 entre os resíduos mutado e o conservado. O histograma Consensus reflete a porcentagem do resíduo modal por coluna (“-“ denota gaps).

Fonte: Própria autoria. 


\subsection{Microscopia Eletrônica de Transmissão}

A análise por microscopia eletrônica de células BF-2 infectadas com a amostra 154 revelou a presença de células com citoplasma marcadamente expandido contendo partículas virais hexagonais intracitoplasmáticas consistentes com virion icosaédrico, em diferentes graus de montagem, dispostas em arranjos paracristalinos, além de partículas em brotamento da membrana plasmática. Ademais, núcleo com condensação de cromatina, indicando apoptose (Figuras 17 e 18).

Figura 17 - Micrografia eletrônica de transmissão de cultivo de BF-2 infectado com a amostra 154.

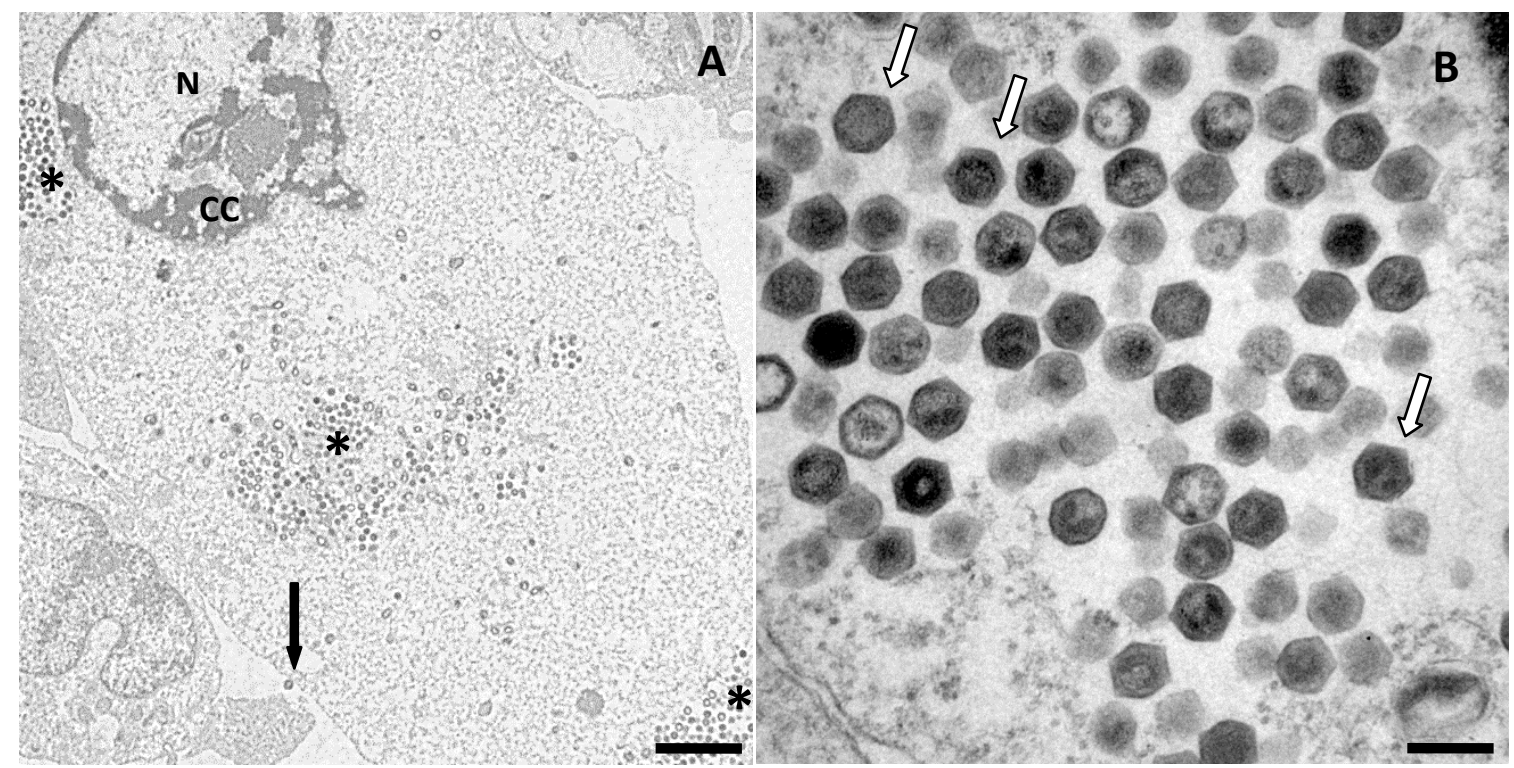

Legenda. Em (A): núcleo (N), condensação de cromatina (CC), indicando apoptose, sítios de montagem de partículas virais em conjunto com arranjos paracristalinos $\left({ }^{*}\right)$ e partícula viral brotando da membrana plasmática (seta). Em B: grande número de virions icosaédricos citoplasmáticos com morfologia consistente com iridovírus (setas brancas). Barra $=900 \mathrm{~nm}($ A) e 200nm (B).

Fonte: Própria autoria. 
Figura 18 - Micrografia eletrônica de transmissão de cultivo de BF-2 infectado com a amostra 154.

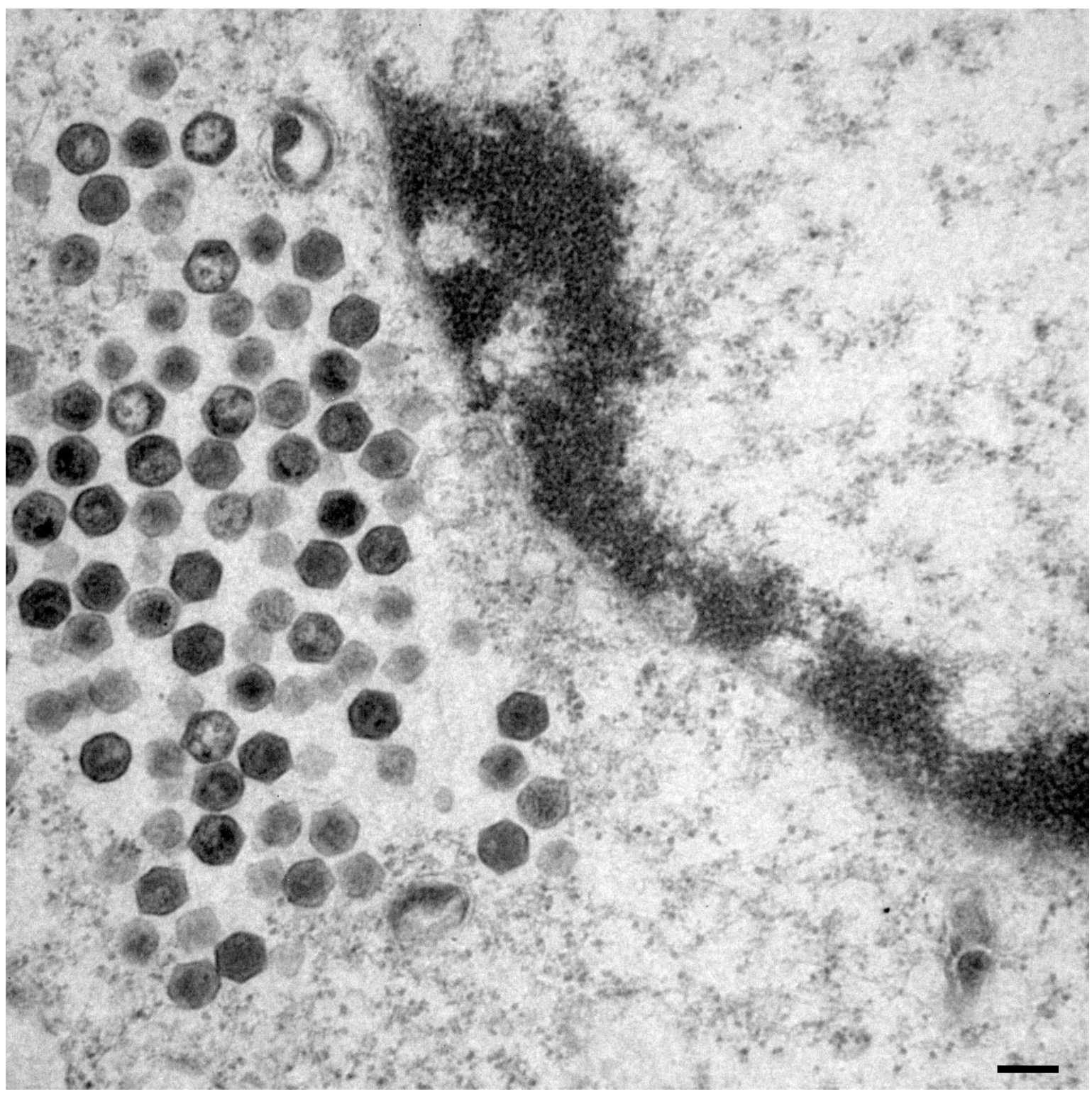

Legenda: Detalhe do arranjo paracristalino próximo ao núcleo celular observado na figura 17. Barra $=170 \mathrm{~nm}$.

Fonte: Própria autoria.

\subsection{Determinação do título viral $\left(\right.$ TCID $\left._{50}\right)$}

O ensaio de diluição limitante permitiu o cálculo do $\mathrm{TCID}_{50} / \mathrm{mL}$ para as novas passagens subsequentes ao isolamento e aos ensaios de replicação e de susceptibilidade. A titulação da quarta passagem (P4) em células do Frog virus 3 isolado da amostra 154 resultou em $10^{4,8} \mathrm{TCID}_{50} / \mathrm{mL}$, enquanto que na passagem seguinte (P5) o título obtido foi de $10^{5,8} \mathrm{TCID}_{50} / \mathrm{mL}$, sendo possível concluir que ocorreu aumento da quantidade de patículas virais decorrente de novas passagens em células. 
Para verificar se ocorrem alterações no título viral quando há congelamento e descongelamento de alíquotas contendo vírus, foi realizada titulação após congelar e descongelar um inóculo da quinta passagem (P5) por três vezes. Um título de $10^{5,72}$ TCID $_{50} / \mathrm{mL}$ foi obtido, demonstrando que não ocorrem alterações significativas no título viral quando este é congelado e descongelado por mais de uma vez, desde que seja mantido refrigerado.

\subsection{Susceptibilidade a solventes}

O teste de susceptibilidade a solventes foi realizado em duplicatas, tendo-se o éter como o agente solvente de lipídeos. A titulação da amostra sem incubação com solvente resultou em $10^{5,8} \mathrm{TCID}_{50} / \mathrm{mL}$, enquanto que a titulação da amostra incubada com éter resultou em $10^{3,79} \mathrm{TCID}_{50} / \mathrm{mL}$, evidenciando diminuição do titulo viral e confirmando a presença de uma população de vírions envelopados.

\subsection{Curva de Replicação}

A titulação viral do cultivo celular, infectado inicialmente com uma diluição 1:100 de $10^{5,8}$ TCID $_{50} / \mathrm{mL}$, e realizada diariamente por 6 dias, demonstrou aumento progressivo durante os quatro primeiros dias após inoculação e uma posterior queda discreta de título viral após o quinto dia (Tabela 3 e Figura 19). 
Tabela 3 - Valores de TCID $_{50} / \mathrm{mL}$ obtidos a partir da curva de replicação viral em cada tempo de coleta.

\begin{tabular}{cc}
\hline Tempo após inoculação & TCID50/mL \\
\hline 1dpi (24h) & $10^{3,97}$ \\
2dpi (48h) & $10^{4,97}$ \\
3dpi (72h) & $10^{5,87}$ \\
4dpi (96h) & $10^{6,8}$ \\
5dpi (120h) & $10^{5,87}$ \\
6dpi (144h) & $10^{5,73}$ \\
\hline
\end{tabular}

Fonte: Própria autoria.

Figura 19 - Curva de replicação: $\mathrm{TCID}_{50} / \mathrm{mL}$ de acordo com o tempo de infecção do ranavírus isolado.

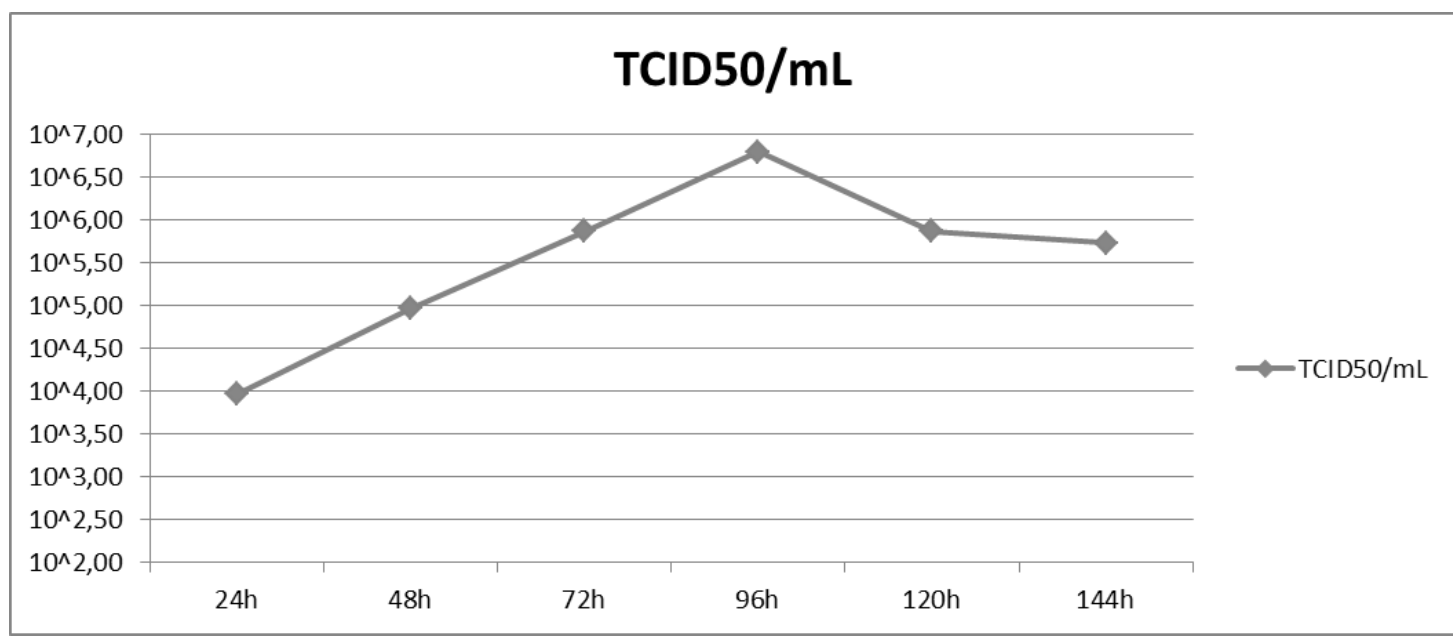

Fonte: Própria autoria. 
Figura 20 - Cultivo celular infectado com a $5^{\mathrm{a}}$ passagem da amostra 154RV em cultura de BF-2 durante os três primeiros dias pós-inoculação para a realização da curva de replicação.

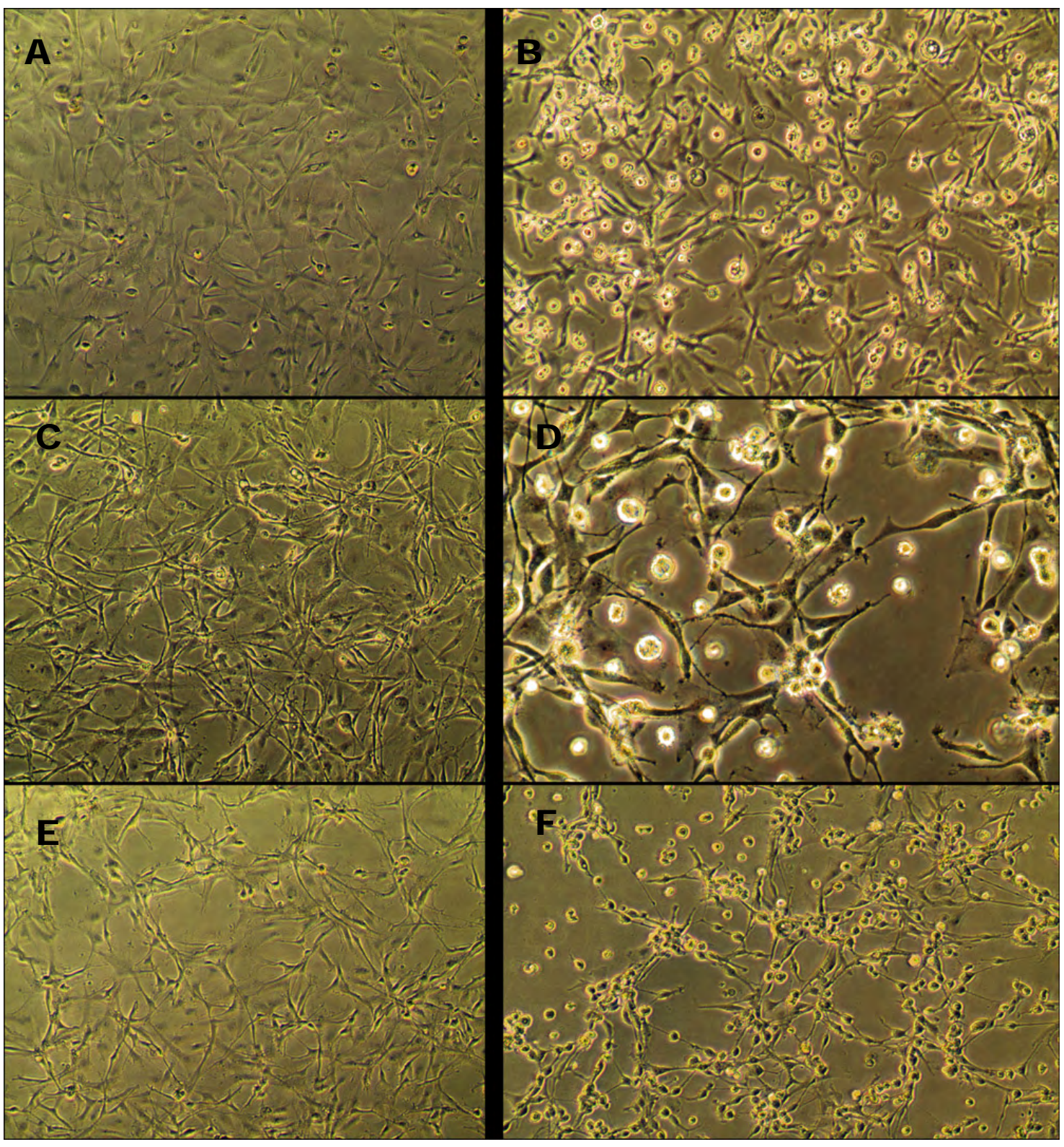

Legenda: A: Controle negativo - monocamada de células BF-2 em meio de manutenção após 24 h. B: Células BF-2 após 24h da inoculação da quinta passagem da amostra 154. Evidências de morte celular. Aumento de 200X. C: Controle negativo - monocamada de células BF-2 em meio de manutenção após 48h. Aumento de 200X. D: Células BF-2 após 48h da inoculação da quinta passagem da amostra 154. Evidências de morte celular e rompimento da monocamada. Aumento de 400X. E: Controle negativo - monocamada de células BF-2 em meio de manutenção após 72h. Aumento de 200X. F: Células BF-2 após 72h da inoculação da quinta passagem da amostra 154. Aumento de 200X.

Fonte: Própria autoria. 
Figura 21 - Cultivo celular infectado com a $5^{\text {a }}$ passagem da amostra 154RV durante os três últimos dias pós-inoculação para a realização da curva de replicação.

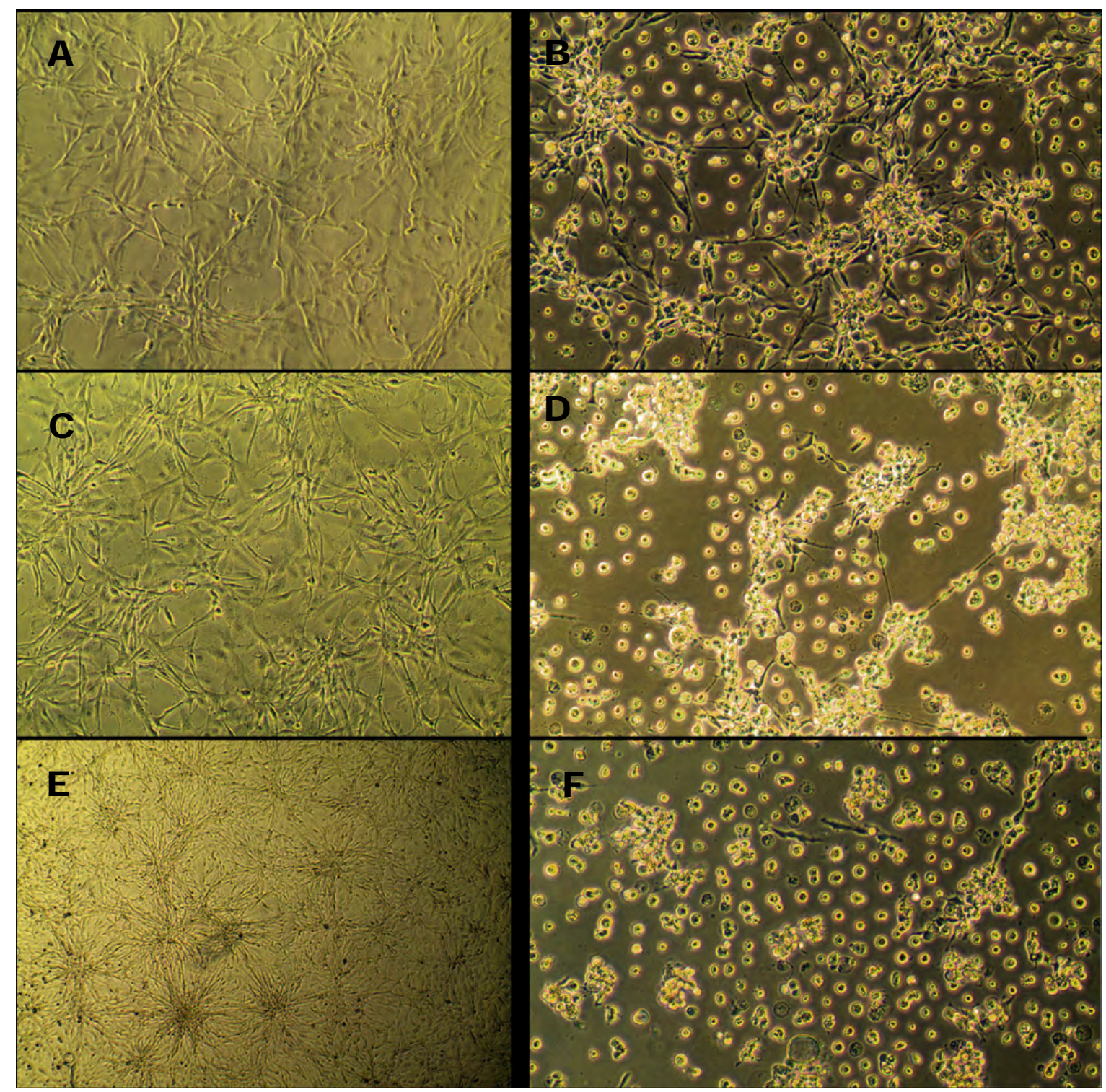

Legenda: A: Controle negativo - monocamada de células BF-2 em meio de manutenção após 96h. Aumento de 200X. B: Células BF-2 após 96h da inoculação da quinta passagem da amostra 154. Destruição da monocamada e aumento de células mortas. Aumento de 200X. C: Controle negativo - monocamada de células BF-2 em meio de manutenção após 120h. Aumento de 200X. D: Células BF-2 após 120h da inoculação da quinta passagem da amostra 154. Destruição completa da monocamada celular. Aumento de 200X. E: Controle negativo - monocamada de células BF-2 em meio de manutenção após 144h. Aumento de 100X. F: Células BF-2 após 144h da inoculação da quinta passagem da amostra 154. Destruição completa da monocamada e morte celular em sua totalidade. Aumento de 200X. Fonte: Própria autoria. 


\section{DISCUSSÃO}

Os resultados do presente estudo foram similares aos anteriormente descritos por Mazzoni et al. (2009) em Goiás, quando investigaram surtos em três propriedades criadoras de rãs, inclusive indicando proximidade genética entre as sequências nucleotídicas obtidas de FV3 (dados ainda não publicados) e também com a sequência protótipo obtida do GenBank (Figura 16) confirmando o papel do gene MCP como um marcador eficaz para a diferenciação das estirpes de Ranavirus (TIDONA et al., 1998). Este estudo também é inédito na identificação de FV3 proveniente de anfíbios adultos no país, uma vez que ambos os estudos realizados anteriormente somente investigaram girinos doentes (MAZZONI et al., 2009; GALLI et al., 2006), confirmando a circulação do agente em diversas etapas de crescimento das rãs.

Em relação ao isolamento em cultivo celular, ambas as amostras positivas causaram efeito citopático na segunda passagem, o que poderia sugerir menor concentração viral nos tecidos coletados quando comparado ao estudo de Speare e Smith (1992) que obtiveram efeito citopático já na passagem inicial, em 48h após inoculação. O efeito citopático obtido foi semelhante ao descrito pela OIE (2012) com lise focal da monocamada celular rodeada por células granulosas arredondadas, incluindo progressão para destacamento e destruição da monocamada, com morte celular completa no decorrer dos dias, assim como ocorreu também no isolamento reportado por Mazzoni et al. (2009), embora usando linhagem celular diferente (Xenopus sp. A6), a partir de girinos infectados. Em tempo, os FV3 podem infectar diversas linhagens celulares (CHINCHAR et al., 2009); portanto, os dados obtidos no presente estudo em conjunto com os de Mazzoni et al. (2009) corroboram com tais características previamente estudadas.

A microscopia eletrônica de transmissão permitiu a visualização das partículas virais intracelulares, confirmando a morfologia do FV3 isolado, assim como foi possível visualizar os arranjos paracristalinos, típicos dos iridovirus. Contudo, não foi possível identificar populações envelopadas nas imagens, como ocorreu no estudo de Speare e Smith (1992) (Figura 22), embora estas populações tenham sido detectadas por meio do teste de suscetibilidade a solventes, onde o título viral caiu significantemente após incubação com éter. No estudo de Speare e Smith (1992), o título (TCID50/mL) caiu de $10^{7,8}$ para $10^{4,3}$ após incubação com solvente, alcançando um percentual de redução de $55 \%$, enquanto que no presente estudo o título viral reduziu de $10^{5,8}$ para $10^{3,79}$, perfazendo uma redução de $65 \%$, ambos confirmando a presença de partículas envelopadas. 
Alguns estudos também utilizam o procedimento de congelar e descongelar o material infectado com FV3 por três vezes (MAZZONI et al., 2009; RING et al., 2013; MAJJI et al., 2006) para que ocorra liberação de mais partículas virais, porém a titulação realizada neste estudo demonstrou que, em verdade, ocorre discreta queda de título (TCID50/mL), de $10^{5,8}$ para $10^{5,72}$, quando realizado congelamento e descongelamento por três vezes, provavelmente devido à liberação de novas populações de partículas envelopadas ser dependente de estruturas celulares viáveis. Ocorreu aumento de título, de $10^{4,8}$ para $10^{5,8}$, quando se propagou sobrenadante de cultuvo infectado proveniente da quarta passagem para uma quinta passagem, corroborando o que foi sugerido.

Figura 22 - Contraste negativo de microscopia eletrônica de transmissão destacando partícula viral envelopada.

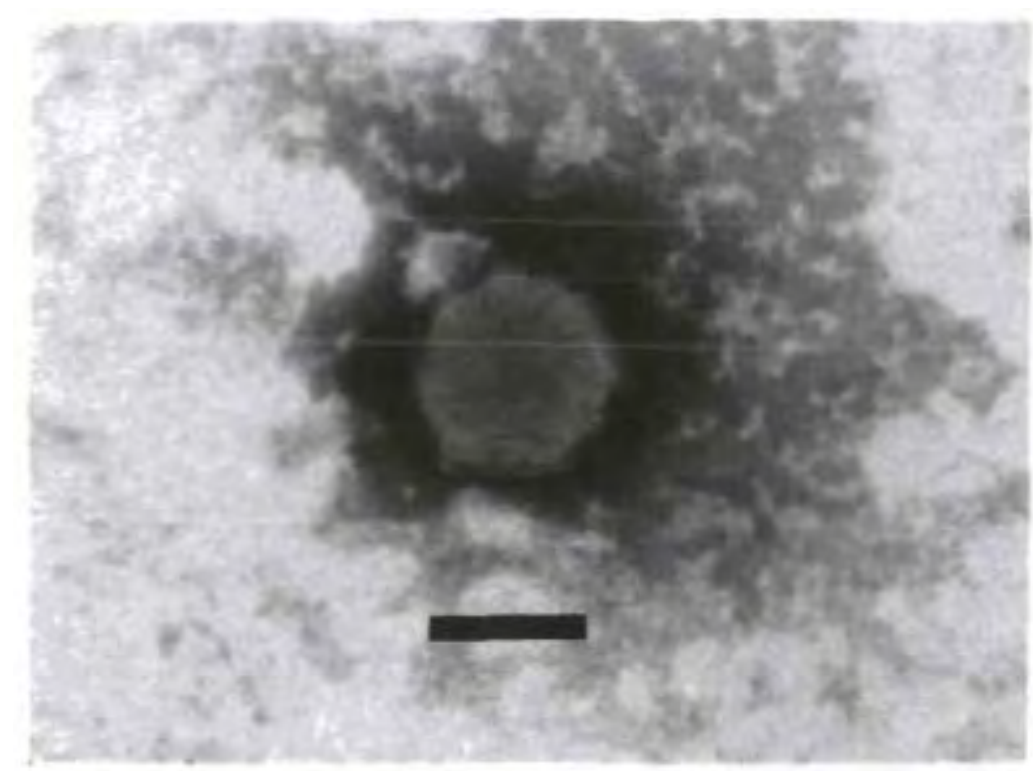

Legenda: 90.000x. Barra: 100nm. Fonte: Speare \& Smith (1992).

Os títulos virais obtidos na curva de replicação foram similares aos descritos por Ariel et al. (2009). No entanto, Holopalainen et al. (2011) relataram que os maiores títulos de FV3 são obtidos em células EPC (Epithelioma papulosum cyprini) cultivadas a $24^{\circ} \mathrm{C}$, dado não evidenciado previamente por Ariel et al. (2009) que, ao realizarem a titulação de FV3 em linhagem EPC durante 6 a 8 dias, obtiveram títulos (TCID50/mL) da ordem de $10^{6,0}$ (Figura 23), após 6 dias de infcção, muito similares ao obtidos na presente investigação $\left(10^{5,73}\right)$. 
Figura 23 - Títulos $\left(\mathrm{TCID}_{50} / \mathrm{mL}\right)$ de dez isolados virais nos dias 6, 8 e 14 após inoculação em células EPC a $24^{\circ} \mathrm{C}$.

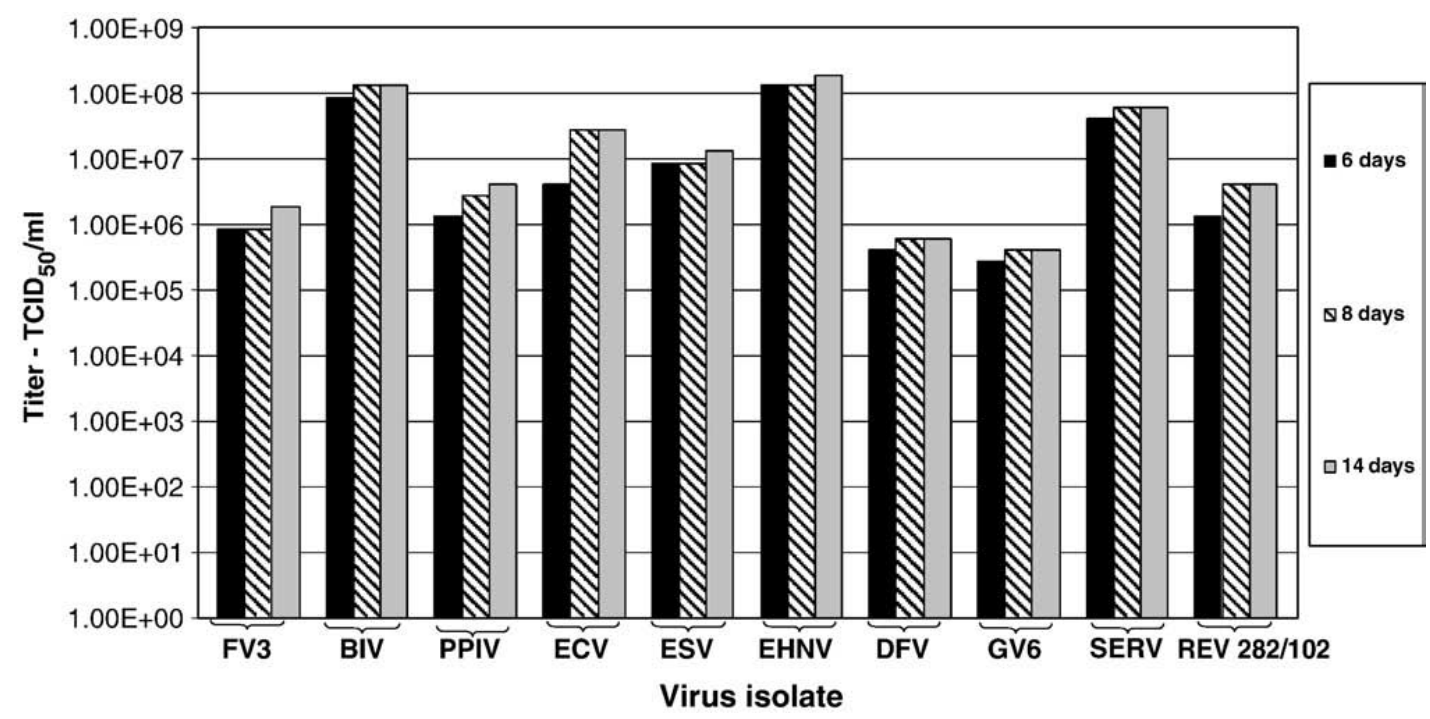

Fonte: ARIEL, E. et al. Propagation and isolation of ranaviruses in cell culture. Aquaculture, Amsterdam, v. 294, p. 159-164, 2009.

No entanto, Speare e Smith (1992) relataram título de $10^{6,5}$ após 7 dias de inoculação, quando FV3 foi cultivado em células BF-2 a $25^{\circ} \mathrm{C}$ (as mesmas condições de cultivo do presente estudo), com um discreto aumento quando comparado aos valores obtidos no último dia da curva de replicação realizada na presente investigação e mesmo em relação aos valores obtidos por Ariel et al. (2009).

A curva de replicação demonstrou aumento de título até o quarto dia (Tabela 3), coincidentemente com a progressão da destruição completa da monocamada e morte celular total (Figuras 20 e 21), sendo que nos dias 5 e 6 já não existiam mais células viáveis, o que pode explicar a discreta queda no título, uma vez que os vírus ficam sujeitos à degradação no meio de cultivo, sem mais células susceptíveis para infectar. Estudos envolvendo diferentes temperaturas de cultivo, resistência do isolado brasileiro à diferentes faixas de $\mathrm{pH}$ e à diferentes temperaturas devem ser realizadas para esclarecer as características deste patógeno.

Os resultados obtidos neste projeto representam a primeira descrição de isolamento de um ranavírus proveniente de amostras de anfíbio no Estado de São Paulo e sua caracterização inicial por PCR, RFLP, microscopia eletrônica de transmissão e em cultivo celular. O isolamento de ranavírus em cultivo celular a partir de amostras positivas 
de anfíbios representa o ponto de partida para inúmeros estudos envolvendo patogenia e imunogenicidade dessa estirpe, que certamente contribuirão com subsídios valiosos para o estabelecimento de medidas de controle da doença nesse setor da aquicultura brasileira. 


\section{CONCLUSÕES}

- Frog Virus 3-símile foi isolado pela primeira vez no Estado de São Paulo a partir de rã-touro gigante adulta.

- O isolamento do FV3 paulista foi confirmado por PCR e RFLP com base no gene MCP, com alta proximidade à estirpe protótipo e também à identificada anteriormente em Goiás.

- A microscopia eletrônica de transmissão confirmou a morfologia iridoviral do isolado obtido, bem como sua distribuição intracelular.

- O teste de susceptibilidade à solventes confirmou a presença de uma população de partículas virais envelopadas.

- A curva de replicação do isolado paulista de FV3 indicou que ocorre aumento progressivo do título viral concomitantemente à destruição progressiva da monocamada celular, com o maior título obtido no quarto dia após inoculação. 


\section{REFERÊNCIAS}

AHNE, W.; SCHLOTFELDT, H. J.; THOMSEN, I. Fish viruses: isolation of an icosahedral cytoplasmic deoxyribovirus from sheatfish (silurus glanis). Journal of Veterinay Medicine B, Berlin, v. 36, n. 5, p. 333-336, 1989.

AHNE, W. et al. Special topic review: iridoviruses associated with epizootic haematopoietic necrosis (EHN) in aquaculture. World Journal of Microbiology and Biotechnology, Dordrecht, v. 13, p. 367-373, 1997.

ALFORD, R. A. Bleak future for amphibians. Nature, London, v. 480, p. 462-463, 2011.

ALTSCHUL, S. F. et al. Gapped BLAST and PSI-BLAST: a new generation of protein database search programs. Nucleic Acids Research, Oxford, v. 25, p. 3389-3402, 1997.

AMPHIBIAWEB. Information on amphibian biology and conservation - web application. 2016. Berkeley, California, 2016. Disponível em:

<http://amphibiaweb.org/>. Acesso em: 27 abr. 2016.

ANTONUCCI, A. M. Caracterização de agentes patogênicos virais e metazoários em rãs-touro, Lithobates catesbeianus, provenientes de ranários comerciais do Vale do Paraíba no Estado de São Paulo, Brasil. 2009. 75 f. Dissertação (Mestrado) Instituto de Pesca, São Paulo, 2009.

ARIEL, E. et al. Propagation and isolation of ranaviruses in cell culture. Aquaculture, Amsterdam, v. 294, p. 159-164, 2009.

BANDIN, I.; DOPAZO, C. P. Host range, host specificity and hypothesized host shift events among viruses of lower vertebrates. Veterinary Research, London, v. 42, art. 67, 2011.

BOLLINGER, T. K. Pathology, isolation, and preliminary molecular characterization of a novel iridovirus from tiger salamanders in Saskatchewan. Journal of Wildlife Diseases, Lawrence, v. 35, n. 3, p. 413-429, 1999.

BRASIL. Ministério da Pesca e Aquicultura. Ministério da pesca consolida legislação para sanidade aquícola. 2015. Disponível em:

<http://www.mpa.gov.br/index.php/ultimas-noticias/2291-mpa-consolida-legislacaopara-sanidade-aquicola-desde-o-cultivo-a-comercializacao>. Acesso em: 05 fev. 2015.

CAMARGO, S. G. O.; POUEY, J. L. O. F. Aqüicultura - um mercado em expansão. Revista Brasileira de Agrociência, Pelotas, v. 11, n. 4, p. 393-396, 2005.

CARRARO, K. C. Ranicultura: um bom negócio que contribui para a saúde. Revista da FAE, Curitiba, v. 11, n. 1, p. 111-118, 2008. 
CHEN, Z. X.; ZHENG, J. C.; JIANG, Y. L. A new iridovirus isolated from soft-shelled turtle. Virus Research, Amsterdam, v. 63, n. 1-2, p. 147-151, 1999.

CHINCHAR, V. G. et al. Iridoviridae. In: REPORT OF THE INTERNATIONAL COMMITTEE ON THE TAXONOMY OF VIRUSES, 8., 2005, London.

Proceedings... London, 2005. p. 163-175.

CHINCHAR, V. G. et al. Family Iridoviridae: poor viral relations no longer. Currente topics in Microbiology and Immunology, New York, v. 328, p. 123-170, 2009.

CULLEN, B. R.; OWENS, L. Experimental challenge and clinical cases of bohle iridovirus (biv) in native australian anurans. Diseases of Aquatic Organisms, Oldendorf, v. 49, p. 83-92, 2002.

CUNNINGHAM, A. A. et al. Experimental transmission of ranavirus disease of common toads (Bufo bufo) to common frogs (Rana temporaria). Epidemiology and Infection, Cambridge, v. 135, p. 1213-1216, 2007.

CUNNINGHAM, A. A. et al. Pathogical and microbiological findings from incidents of unusual mortality of the common frog Rana temporaria. Philosophical Transactions of the Royal Society of London, London, v. 351, p. 1539-1557, 1996.

DASZAK, P. et al. Emerging infectious diseases and amphibian population declines. Emerging infectious Diseases, Atlanta, v. 5, n. 6, p. 735-748, 1999.

DOCHERTY, D. E. et al. Diagnostic and molecular evaluation of three iridovirusassociated salamander mortality events. Journal of Wildlife Diseases, Lawrence, v. 39, n. 3, p. 556- 566, 2003.

DRURY, S. E. N.; GOUGH, R. E.; CALVERT, I. Detection and isolation of an iridovirus from chameleons (chamaeleo quadricornis and chamaeleo hoehnelli) in the United Kingdom. Veterinary Record, London, v. 150, p. 451-452, 2002.

DUFFUS, A. L. J. et al. Distribution and host range of ranaviruses. In: GRAY, M. J.; CHINCHAR, V. G. (Eds.). Ranaviruses: lethal pathogens of ectothermic vertebrates. New York: Springer International Publishing, 2015. p. 9-57.

FERREIRA, C. M. Ranicultura. 2004. Disponível em:

<ftp://ftp.sp.gov.br/ftppesca/ranicultura.pdf>. Acesso em: 10 fev. 2014.

FERREIRA, C. M.; PIMENTA, A. G. C.; PAIVA NETO, J. S. Introdução a ranicultura. Boletim Técnico do Instituto de Pesca, São Paulo, n. 33, 2002. 15 p.

FOOD AND AGRICULTURE ORGANIZATION OF THE UNITED NATIONS FAO. The state of world fisheries and aquaculture. Rome: FAO, 2014.

Fish to 2030: prospects to fisheries and aquaculture. 2013. Disponível em: <http://www.fao.org/docrep/019/i3640e/i3640e.pdf>. Acesso em: 10 fev. 2015. 
FIGUEIREDO, H. C. P.; LEAL, C. A. G. Tecnologias aplicadas em sanidade de peixes. Revista Brasileira de Zootecnia, Viçosa, v. 37, p. 8-14, 2008.

FOX, S. F. et al. First case of ranavirus-associated morbidity and mortality in natural populations of the South American frog Atelognathuspatagonicus. Diseases of Aquatic Organisms, Oldendorf, v. 72, p. 87-92, 2006.

FROST, D. R. et al. The amphibian tree of life. Bulletin of the American Museum of Natural History, New York, n. 297, p. 257-291, 2006.

GALLI, L. et al. Ranavirus detection by PCR in cultured tadpoles (Rana catesbeiana Shaw, 1802) from South America. Aquaculture, Amsterdam, v. 257, p. 78-82, 2006.

HALL, T. A. BioEdit: a user-friendly biological sequence alignment editor and analysis program for Windows 95/98/NT. Nucleic Acids Symposium Series, Oxford, v. 41, p. 95-98, 1999.

HIPOLITO, M. et al. Detecção ao microscópio eletrônico de transmissão de partículas virais semelhantes aos grupos Herpes, Toga e Paramyxovirus em rã-touro (Ranacatesbeiana Shaw, 1802) criadas comercialmente. Primeiras observações no Brasil. Arquivos do Instituto Biológico, São Paulo, v. 70, n. 1, p. 107-111, 2003.

HOLOPALAINEN, R. et al. Quantitation of ranaviruses in cell culture and tissue samples. Journal of Virological Methods, Amsterdam, v. 171, p. 225-233, 2011

HYATT, A. D. et al. First identification of a ranavirus from green pythons (chondropython viridis). Journal of Wildlife Diseases, Lawrence, v. 38, n. 2, p. 239252, 2002.

ICTVDS Management 00.036. Iridoviridae. In: BÜCHEN-OSMOND, C. (Ed.). ICTVdB - The universal virus database, version. New York: Columbia University, 2006.

INTERNATIONAL UNION FOR CONSERVATION OF NATURE AND NATURAL RESOURCES - IUCN. Amphibians. 2008. Disponível em:

<http://www.iucnredlist.org/initiatives/amphibians/analysis>. Acesso em: 10 dez. 2014.

LANGDON, J. S. et al. First virus isolation from australian fish: An iridovirus-like pathogen from redfin perch, perca fluviatilis l. Journal of Fish Diseases, Chichester, v. 9, n. 3, p. 263-268, 1986.

LESBARRÈRES, D. et al. Ranavirus: past, present and future. Biological Letters, Poland, v. 8, p. 481-483, 2012.

LIMA, S. S.; CRUZ, T. A.; MOURA, O. M. Ranicultura: análise da cadeia produtiva. Viçosa: Editora Folha de Viçosa, 1999. 172 p.

LIMA, S. L.; AGOSTINHO, C. A. A tecnologia da criação de rãs. 2. ed. Viçosa: Imprensa Universitária, 1995. 170 p. 
MAJJI, S. et al. Rana catesbeiana virus Z (RCV-Z): a novel pathogenic ranavirus. Diseases of Aquatic Organisms, Oldendorf, v. 73, p. 1-11, 2006.

MAO, J.; HEDRICK, R. P.; CHINCHAR, V. G. Molecular characterization, sequence analysis, and taxonomic position of newly isolated fish iridoviruses. Virology, Waltham, v. 229, n. 1, p. 212-220, 1997.

MARSH, I.B. et al. Rapid differentiation of Australian, European and American ranaviruses based on variation in major capsid protein gene sequence. Molecular and cellular probes, 16, p. 137-151, 2002

MARSCHANG, R. E. et al. Isolation and characterization of an iridovirus from hermann's tortoises (testudo hermanni). Archives of Virology, Wien, v. 144, n. 10, p. 1909-1922, 1999.

MARTINS, A. M. C. R. P. F.; HIPOLITO, M.; CATROXO, M. H. B. A importância da piscicultura e algumas doenças virais e bacterianas písceas. Comunicados Técnicos, São Paulo, art. 156, 2011. Disponível em:

< http://www.biologico.sp.gov.br/artigos_ok.php?id_artigo=156>. Acesso em: $10 \mathrm{dez}$. 2014.

MAZZONI, R. Infecções por Ranavirus e cocos Gram-positivos em girinos e rãs de criação (Rana catesbeiana Shaw, 1802) do estado de Goiás. 2006. 146 f. Tese (Doutorado) - Universidade Federal de Goiás, Goiânia, 2006.

MAZZONI, R. et al. Mass mortality associed with a frog vírus 3-like ranavírus infeccion in farmed tadpoles Rana catesbiana from Brasil. Diseases of Aquatic Organisms, Oldendorf, v. 86, n. 3, p. 181-191, 2009.

MESQUITA, A. Q. Síndrome vestibular em Lithobates catesbeianus associada à Ranavirus. 2014. 80 f. Tese (Doutorado) - Universidade Federal de Goiás, Goiânia, 2014.

MINISTÉRIO DA PESCA E AQUICULTURA. Consolidação de uma política de estado para o desenvolvimento sustentável da aquicultura e pesca. 3a Conferência Nacional de Aquicultura e Pesca, p.80, 2009.

MILLER, D.; GRAY, M.; STORFER, A.; Ecopathology of Ranaviruses Infecting Amphibians. Viruses, Basel, v.3, n 11, p. 2351-2373, 2011.

NAKAJIMA, K.; INOUYE, K.; SORIMACHI, M. Viral diseases in cultured marine fish in japan. Fish Pathology, Tokyo, v. 33, p. 181-188, 1998.

OFFICE INTERNATIONAL DES EPIZOOTIES - OIE. Infection with Ranavirus. In: . Manual of diagnostic tests for aquatic animals. Paris: OIE, 2012. p. 1-21

. OIE listed diseases. Paris: OIE, 2016.

OLIVEIRA, E. G. Ranicultura: novos desafios e perspectivas do mercado. Ciência Animal, Fortaleza, v. 25, n. 1, p. 173-186, 2015. 
PEREIRA, S. A. et al. Sanidade e perspectivas para ranicultura. In: TAVARES-DIAS, M.; MARIANO, W. S. (Orgs.). Aquicultura no Brasil: novas perspectivas. São Carlos, SP: Pedro e João Editores, 2015. v. 1, cap. 14, p. 236-277.

PLUMB, J. A. et al. An iridovirus isolated from wild largemouth bass. Journal of Aquatic Animal Health, New York, v. 8, n. 4, p. 265-270, 1996.

REED, L. J.; MUENCH, H. A simple method of estimating fifty percent endpoints. American Journal of Hygiene, Cary, v. 27, p. 493-497, 1938.

RING, B. A. et al. Frog virus 3 open reading frame 97r localizes to the endoplasmic reticulum and induces nuclear invaginations. Journal of Virology, Washington, v. 87, n. 16, p. 9199-9207, 2013.

RODRIGUES, C. A. G. et al. Áreas potenciais para a criação de rã-touro gigante Lithobates catesbeianus (Shaw, 1802) na região Sudeste do Brasil. Campinas: Embrapa Monitoramento por Satélite, 2010. 37 p. (Embrara Monitoramento por Satélite. Boletim de Pesquisa e Desenvolvimento, 12).

SCORVO, D. J. O agronegócio da aqüicultura: perspectivas e tendências. In: CONGRESSO NACIONAL DE ZOOTECNIA, 14., 2004, Brasília. Anais... Brasília: UPIS, 2004. 1 CD-ROM.

SOCIEDADE NACIONAL DE AGRICULTURA - SNA. Brasil é segundo na produção mundial de rãs. Disponivel em: $<$ http://sna.agr.br/brasil-e-segundo-naproducao-mundial-de-ras/>. Acesso em: 03 maio 2016.

SPEARE, R.; SMITH, J. R. An iridovirus-like agent isolated from the ornate burrowing frog Limnodynastes ornatus in northern Australia. Diseases of Aquatic Organisms, Oldendorf, v. 14, p. 51-57, 1992.

TELFORD, S. R. J.; JACOBSON, E. R. Lizard erythrocytic virus in east African chameleons. Journal of Wildlife Diseases, Lawrence, v. 29, n. 1, p. 57-63, 1993.

TIDONA, C. A. et al. Is the major capsid protein of iridoviruses a suitable target for the study of viral evolution? Virus Genes, New York, v. 16, p. 59-66, 1998.

THOMPSON, J. D. et al. The CLUSTAL_X windows interface: flexible strategies for multiple sequence alignment aided by quality analysis tools. Nucleic Acids Research, Oxford, v. 25, p. 4876-4882, 1994.

WATERHOUSE, A. M. et al. Jalview Version 2-amultiple sequence alignment editor and analysis workbench. Bioinformatics, Oxford, v. 25, p. 1189-1191, 2009.

WHITTINGTON, R. J.; BECKER, J. A.; DENNIS, M. M.; Iridovirus infections in finfish - critical review with emphasis on ranaviruses. Journal of Fish Diseases, Chichester, v. 33, p. 95-122, 2010. 
WILLIAMS, T.; BARBOSA-SOLOMIEU, V.; CHINCHAR, V. G. A decade of advances in iridovirus research. Advances in Virus Research, v. 65, p. 173-248, 2005.

WOLF, K. et al. Tadpole edema virus: a viscerotropic pathogen for anuran amphibians. The Journal of Infectious Diseases, Cary, v. 118, n. 3, p. 253-262, 1968.

ZHANG, Q. Y. et al Characterization of an iridovirus from the cultured pig frog (Rana grylio) with lethal syndrome. Diseases of Aquatic Organisms, Oldendorf, v. 48, p. 2736, 2001.

ZUPANOVIC, Z. et al. Isolation and characterization of iridoviruses from the giant toad Bufomarinus in Venezuela. Diseases of Aquatic Organisms, Oldendorf, v. 33, p. 1-9, 1998. 


\section{ANEXOS}

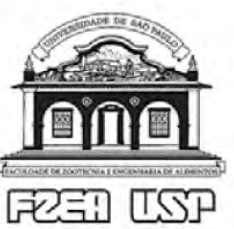

UNIVERSIDADE DE SÃO PAULO

Faculdade de Zootecnia e Engenharia de Alimentos Comitê de Ética em Pesquisa da FZEA

\section{CERTIFICADO}

Certificamos que o Projeto intitulado "Isolamento e caracterização de estirpe de Frog Virus 3-símile detectada em rãs-touro gigante (Lithobates catesbeianus) no Estado de São Paulo. ", protocolado sob o CEUA n ${ }^{0} 1629310316$, sob a responsabilidade de Ricardo Luiz Moro De Sousa e equipe; Anna Luiza Farias Alencar - que envolve a produção, manutenção e/ou utilização de animais pertencentes ao filo Chordata, subfilo Vertebrata (exceto o homem), para fins de pesquisa científica (ou ensino) - encontra-se de acordo com os preceitos da Lei 11.794, de 8 de outubro de 2008, com o Decreto 6.899 , de 15 de julho de 2009 , com as normas editadas pelo Conselho Nacional de Controle da Experimentação Animal (CONCEA), e foi aprovado pela Comissão de Ética no Uso de Animais da Faculdade de Zootecnia e Engenharia de Alimentos da Universidade de São Paulo - FZEA/USP em reunião de $18 / 05 / 2016$.

We certify that the proposal "Isolation and characterization of Frog Virus 3-like strain detected in american bull frogs (Lithobates catesbeianus) in São Paulo State.", utilizing 8 Amphibians (males and females), protocol number CEUA 1629310316, under the responsibility of Ricardo Luiz Moro De Sousa and team; Anna Luiza Farias Alencar - which involves the production, maintenance and/or use of animals belonging to the phylum Chordata, subphylum Vertebrata (except human beings), for scientific research purposes (or teaching) - it's in accordance with Law 11.794, of October 82008 , Decree 6899, of July 15, 2009, with the rules issued by the National Council for Control of Animal Experimentation (CONCEA), and was approved by the Ethic Committee on Animal Use of the School of Animal Science and Food Engineering of São Paulo University in the meeting of 05/18/2016.

Vigência da Proposta: de 04/2014 a 10/2016

Área: Medicina Veterinária

Procedência: Não aplicável

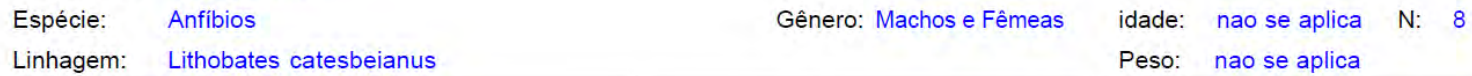

Nota: A aquicultura é apontada como um mercado estratégico para o desenvolvimento sustentável, produção de alimentos e ampliação de fronteiras inexploradas no Brasil. No entanto, como outros sistemas de produção animal, este setor enfrenta problemas com doenças resultantes de sua intensificação, como os aspectos sanitários da produção e a falta de estrutura para o diagnóstico das principais enfermidades infecciosas. Durante os últimos 20 anos, os vírus da família Iridoviridae, em especial membros do gênero Ranavirus, têm sido responsáveis por epizootias de grande impacto ecológico e econômico, envolvendo um grande número de espécies de peixes, anfíbios e répteis de importância na aquicultura de várias partes do mundo. No entanto, as informações sobre a ocorrência de infecções de peixes e anfíbios causadas por ranavírus no Brasil são limitadas. Nesse contexto, os objetivos deste projeto serão: realizar 0 isolamento em cultivo celular de estirpe de Frog Virus 3-símile, detectada no Estado de São Paulo, com sequenciamento nucleotídico completo do gene $\mathrm{MCP}$, e proceder à caracterização fenotípica e de cinética de replicação do isolado. Amostras de fígado, baço e rins de rãs-touro gigante provenientes de ranário comercial, positivas ao diagnóstico molecular para Ranavirus, serão utilizadas para isolamento viral em cultivo celular. Além do isolamento, a caracterização viral será feita a partir da construção da curva de crescimento, ensaio de placa e sensibilidade ao clorofórmio. Acredita-se que os resultados obtidos nesse estudo poderão contribuir para a compreensão da biologia de iridovírus circulante como agente etiológico de ranavirose em anfíbios no Estado de São Paulo.

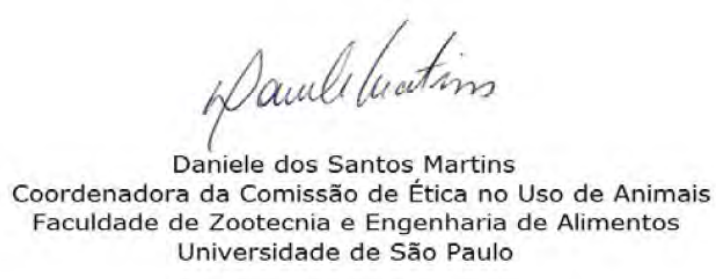

